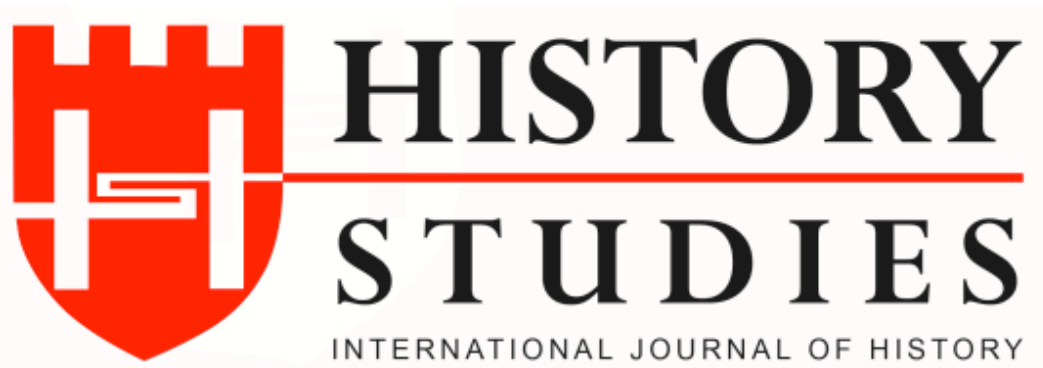

ISSN: 13094173 (Online) 1309 - 4688 (Print)

Volume 9 Issue 5, p. 107-127, December 2017

DOI: $10.9737 /$ hist.2017.562

\title{
Ensar Kimliğinin Oluşumuna Etki Eden Faktörler
}

The Factors Creating the Ansar Identity

\author{
Yrd. Doç. Dr. Abdurrahman DEMİRCİ \\ (ORCID: 0000-0003-2369-1847) \\ Mardin Artuklu Üniversitesi - Mardin
}

\begin{abstract}
Öz: Arap yarımadasında hakim kültür, dini açıdan şirk; siyasi açıdan ise asabiyetti. Değerler karmaşası olan şirk ve adaletsizlikleri meşru kılan asabiyet kültürü nedeniyle Evs-Hazrec, Arap yarımadasında iç savaşı en yoğun yaşayan kabile olmuştur. Bir asrı aşan bu çatışma süreci, bir kısır döngü olmasının yanı sıra Medine'yi de yaşanmaz hale getirmiştir. Medineli Müslümanlar, İslam'ı kabul ederek bu her iki unsurun yerine Islam'ı koymuşlardır. Evs-Hazrec, başta Kureyş olmak üzere tüm müşrikleri karşısına alıp İslam'ı himaye işine koyulmuş; mal, can ve nesil olmak üzere her şeyini kaybetme pahasina da olsa bu uğurda ısrarcı olmuştur. Ancak İslam Tarihi alaninda yapilan çalışmalarda Ensar kimliği genelde yapılan maddi fedakârlıklar öne çıkartılmak suretiyle tanıtılır. Kendileri ise hiç bir zaman bu husus üzerinden Ensar'ı tanımlamamıştır. Ensar'ı tanıyabilmek için bu karakteri meydan getiren unsurları bilmek gerekir. Biz bu çalışmamız ile Ensar kimliğini oluşturan unsurların kendi iç çatışmalarının oluşturduğu yıkımlar başta olmak üzere, ilahi yardım, Hz. Peygamber'in yoğun gayretleri, kendi fedakârlıklart ve cesaretleri olduğunu gördük. Tüm bu etkenler ile Ensar kimliğinin kabile kültürüne alternatif oluşturduğunu ve bir sıfatın nasıl nesep gibi işlev gördüğ̈̈nü tespit ettik.
\end{abstract}

Anahtar Kelimeler: Ensar, Akabe, Neseb, Diğergamlı, Evs-Hazrec

Abstract: The dominant culture in the Arabian Peninsula was Shirk religiously and Asabiyyah politically. Evs-Hazrec experienced the civil war the most intensively in the Arabian Peninsula due to Shirk, which is complexity of values and Asabiyyah, which legitimizes societal injustice. This period of conflict lasting more than a century, in addition to be a vicious circle, created unliveable conditions in Madina. The Muslims of Madina replaced these two elements with Islam by embracing Islam. Evs-Hazrec confronted all the Mushriks, notably Kureys in order to guard Islam at the risk of loss of life, property and generation. However, the studies in History of Islam introduce the 'Ansar identity' with the emphasis on the material sacrifices and lack their effort to defend Islam. It is essential to define the elements that shaped the Ansar characteristic to be able to identify the Ansar. We study the role of divine help, the prophet's efforts, Ansar's sacrifices and courage and notably the destruction originated from the internal conflict within Evs-Hazrec on the formation of Ansar identity. We seek to find out how this Ansar identity became an alternative to tribal culture and how a character functioned like a lineage.

Keywords: Ansar, Akaba, Lineage, Generosity, Aws and Khazraj

\section{Giriş}

Hz. Muhammed, risaletin Mekke döneminde Kureyş müşriklerinin yoğun baskısına bir çözüm olması amacıyla Müslümanlara Habeşistan'a hicreti tavsiye etmiştir. Ancak "Allah bir yol gösterinceye kadar"1 açıklaması ile de bu çözümü muvakkat bir tedbir olarak nitelemiştir.

\footnotetext{
${ }^{1}$ Ebû Muhammed Cemaleddin İbn Hişam, es-Sîretu'n-Nebeviyye, C. I, thk. Mustafa es-Sekka, İbrahim el-Ebyâri, Abdülhafız Şelebî, Dâru İhyai’t-Turâsi'l-Arabi, Beyrut, t.y., s. 344.
} 
Hicret için Habeşistan'ın tercih edilmesinin nedeni, Hz. Peygamber'in Habeş kralını adil olarak tanımlamış olmasıdır. Habeş kralı Necaşi'nin ardından idareyi ele alacak kişinin tavrı bilinemeyeceği ya da hâlihazırda temelli bir hicret yurdu arayışında olduğu için $\mathrm{Hz}$. Peygamber, böyle bir açıklama yapmış olabilir. Dolayısıyla bu hicretin nedeni, Habeşistan'da İslam'ı yaymak veya bu hamle ile Mekke'de temerküz etmiş şirk yapısını bertaraf etmek değildi. Çünkü Habeşistan'da kurumsallaşmış bir Hıristiyanlık egemendi ve Müslümanların yegâne amacı da an itibariyle zulümden kurtulmaktı. Nitekim buradan kısa sürede dönüşler olmuş ve Medine hicreti ile birlikte Habeşistan muhacirleri son hicretlerini Medine'ye yapmıştır. Burada konumuz açısından değinmemiz gereken husus, Habeşistan'a hicret edenlerin burada karşılaştıkları muameledir. Kureyş'in aleyhteki yoğun çabalarına rağmen, Habeşistan kralı en-Necâşî Ashame b. Ebcer tarafından sahiplenilen Müslümanlar, burada herhangi bir baskı ile karşılaşmamışlardır. Necâşînnin Müslüman olarak öldüğüne dair rivayetler ${ }^{2}$ yanında Müslümanları himayesi ve maddi yardımlarına rağmen ${ }^{3}$ Necaşi ve çevresi için Ensar sıfatı kullanılmamıştır. Bunun başlıca sebepleri, muhtemelen burada kitlesel bir İslamlaşmanın sağlanamaması ve İslam için maddiyatı aşacak derecede fedakârlıkların gerçekleşmeyişidir. Ancak Evs-Hazrec kabilelerinin varlı̆̆ı, İslam kültüründe öyle yer etmiştir ki bu iki kabileye Ensaradı verilmiş ve kendileri adeta Ensar ismiyle müşahhas hale gelmiştir. Nitekim Ensar, Hz. Peygamber'in ashabından bir kesimi nitelemek için, diğer bütün isimlerin yerini almış ve adeta bir kabile gibi anılır olmuştur. ${ }^{4} \mathrm{Bu}$ doğrultuda Medine şehri, İslam kültüründe gördüğü işlev yönüyle farklı isimlere layık görülmüştür. Nitekim halkının Müslümanlara olan sadakati nedeniyle Medine'ye verilen isimlerden birisi de Karyetu'lEnsar'dir. ${ }^{5}$

Ensar üzerine yapılan değerlendirmelerde, genelde maddi fedakârlıklara odaklanılır ancak Ensar kimliğini meydana getiren unsurlara değinilmez. Hatta bazan yapılan maddi fedakârlıklar, Ensar karakterinin önemini gösterme adına akıl almaz boyutlara vardırılır. Fakat nedense Evs-Hazrec'in kendisi, maddi fedakârlıkları ile övünmek yerine Hz. Peygamber'i ve Müslümanları himaye noktasında yaptıklarına dikkat çeker. Çünkü Ensar'ı tanımlarken öne çıkarılan maddi fedakârlıklar, belirli bir zaman dilimi için geçerlidir. Ancak İslam'ı savunma ve himaye hususları Ensar toplumu var olduğu müddetçe devam etmiştir. İŞte biz bu çalışmamızda Ensar kimliğini oluşturan ilahi ve beşeri faktörleri siyer kaynaklarında yer alan rivayetler 1şı̆̆ında ele alıp inceleyeceğiz.

\section{Tebliğin Muhatabı Kabileler ve Evs-Hazrec}

Hz. Peygamber'in tebliğ yolunda harcadığı çaba, olağanüstü niteliktedir. Bu durum Kuran'da bir eleştiri olarak bile yer almıştır. ${ }^{6}$ Bir beşerin tahammül etmede zorlanacağ tebliğ çalışmaları, İslam Tarihi kaynaklarında ayrıntılı bi şekilde yer almaktadır. Amcası Ebu Talib'in vefatı ardından üzerindeki baskılar giderek artınca Taif'e bir yolculuk tertipleyen Hz. Peygamber, burada da olumsuzluklarla karşılaşmıştır. Ancak ümitsizliğe düşmemiş ve Taif dönüşü Mekke'ye girmesinin imkânsızlığına rağmen yoluna devam etmiştir. Şüphesiz bunun izahı, yine asabiyetle yapılabilir. Kendisini ambargo yılında asabiyetle koruyan Benî Haşim'den sonra, bu kez de Benî Huzâ'dan Mut'im b. Adiy devreye girmiştir. ${ }^{7}$ Çünkü asabiyet,

\footnotetext{
${ }^{2}$ Ebû Abdullah Muhammed b. İsmail Buhari, Sahîhu'l-Buhârî, Menakıbu'l-Ensar, 38.

${ }^{3}$ Buhari, Menâkıbu'l-Ensar, 38.

${ }^{4}$ Ebû'l-Fazl Muhammed İbn Manzur, Lisânu'l-Arab, C. XIV, thk. Emin Muhammed Abdulvehhab, Muhammed Sadık el-Ubeydi, Dâru İhyai Turâsi'l-Arabî, Beyrut 1999, s. 160.

${ }^{5}$ Nureddin Ali es-Semhûdî, Vefâu'l-Vefâ bi Ahbâri Dâri'l-Mustafa, C. I, thk. Muhammed Muhyiddin Abdülhamid, Beyrut 1984, s.19.

6 "İman etmiyorlar diye neredeyse kendine kıyacaksın" eş-Şuarâ 26/3.

${ }^{7}$ İbn Sad, age, C. I, s. 181.
} 
Mekke dönemindeki tüm olumsuzluklar içinde Hz. Peygambere tebliğ imkanı ve hayat hakkı sağlayan önemli bir firsattı. ${ }^{8}$ Ancak İslam şirk kültürü için tehlike arz etmeye başladığı andan itibaren asabiyet, tebliğe imkân vermemiş, sadece hayat garantisine yardımcı olmuştur.

Tebliğin açıktan yapılmaya başlandığı 4. yıldan itibaren Hz. Peygamber her hac mevsimini firsat olarak değerlendirmiştir. Nitekim Hz. Peygamber; Benî Amir b. Sa'saa, Muharib b. Hasafe, Fezâre, Gassân, Mürre, Hanîfe, Süleym, Abs, Benî Nadr, Benîl-Bukâ, Kinde, Kelb, el-Hâris b. Ka'b, Uzre ve el-Hadârime olmak üzere birçok kabileye tebliğde bulunmuştur. ${ }^{9}$ Her kabileye tebliğde bulunmakla birlikte caydırıcı olması hasebiyle ismi ve şerefi ile ünlü kabileleri daha fazla tercih etmiştir. ${ }^{10}$ Bu süreçte bazılarının davete verdikleri cevapların daha olumsuz ya da ümit var olması ${ }^{11}$ nedeniyle, genelde bu kabilelerin isimleri kaynaklarda yer almıştır. Tebliğe olumsuz cevap verenlerin dayanağı, Kureyş eşrafının muhalefeti ve aleyhteki faaliyetleridir. ${ }^{12}$ Mekke'ye gelen onlarca kabileye İslâm'1 tebliğ edip, kendisine ve Müslümanlara sığınacak bir yurt arayan Hz. Muhammed, Kureyş'in takibi ve yalanlama çabaları sebebiyle çağrısına olumlu karşılık bulamamıştır. Kureyş'in aleyhteki faaliyetleri, kabilelerin Hz. Peygamber'in tebliğ çalışmalarına ön yargıyla bakmalarına sebep olmuştur. ${ }^{13}$

Hz. Peygamber'e verilen cevaplar, kabilevî yaşamın mantığını ve yarımadadaki siyasi dengeleri özetler nitelikteydi. ${ }^{14}$ Kabilelerin İslam'a olumlu cevap vermemesinde, ikna sürecinden ziyade, içinde bulundukları şartların da önemli bir payı vardır. Çünkü çoğunluğu, kabile içi çatışmalara çözüm aramak için değil, sadece dini ritüellerini ifa etmek için Mekke’ye gelmekteydi. Dolayısıyla bu şartlarda Kureyş kabilesini karşılarına almak, cesaret gerektiren başlıca bir sorundu. Başta Benî Hanîfe olmak üzere, kabilelerin genel anlamda tebliğe olumsuz hatta yer yer sert tepkiler vermesinde ise değişime kapalı olan bedevi kültür oldukça etkilidir. ${ }^{15}$

Tüm kabileler Arap kabile mantığı itibariyle zaman zaman bir takım çekişme ve mücadeleler içindeydi. Ancak bunlar içinde en büyük sıkıntıların yaşandığ Medine'den gelenlerdi. Çünkü diğerleri Mekke'ye hac için gelirken bunlar, kendi kardeş kabilelerine karșı ittifak arayıșı içindeydi. Her önemli kabile gibi Benî Kayle (Evs ve Hazrec'in annelerine nispetle ortak ad 1$)^{16} \mathrm{de} \mathrm{Hz}$. Peygamber'in İslam'a kazandırmaya çalıștığ 1 büyük bir kabile idi. Hz. Peygamber, akrabalık bağlarının yanı sıra Hicaz Yahudilerinin yurdu olması yönüyle de burayı iyi bilmekteydi. ${ }^{17}$ Şüphesiz hicretin yapılacağı mekân olan Medine'nin, Mekke'nin kuzey ticaret yolları üzerinde bulunuyor olması, ileride gerçekleşen gazve ve seriyyelerden de anlaşılacağı üzere Mekke ticareti için büyük bir engeldi. Ancak bu durum, Hz. Peygamber'in Medine'yi hicret yeri olarak seçme nedenlerinden ziyade sonuçları arasında sayılabilir. Çünkü Hz. Peygamber'in tebliğ yaparken yegâne hedefi, İslam'a güvenli bir yurt ve müntesipler kazandırmaktı.

\footnotetext{
${ }^{8}$ Muhammed Abid el-Cabiri, Arap-İslam Siyasal Aklı, çev. Vecdi Akyüz, Kitabevi yay., İstanbul 2001, s. 112.

9 İbn Sad, Kitabu't-Tabakâti'l-Kebir, C. I, s. 184.

${ }_{10}$ İbn Hişam, age, C. II, s. 67; Ebû'l-Kâsım Abdurrahman es-Süheyli, er-Ravdu'l-Unûf fì Şerhi's- Sîreti'nNebeviyye li-İbn Hişam, C. II, Dâru'l-Kutubi'l-İlmiyye, Beyrut, t.y., s. 241.

${ }^{11}$ Belâzurî, Kinde kabilesinin oldukça yumuşak bir tavır sergilediğini aktarır. Bkz. Ebû'l-Abbas Ahmed Belâzurî, Ensâbu'l-Eşrâf, thk. Muhammed Hamidullah, Dâru'l-Meârif, C. I, Misır 1959, s. 238.

12 İbn Sa'd, age, C. I, s. 184.

13 Takıyuddin Ahmed b. Ali el-Makrizi, Imtau'l-Esma, C. I, thk. Muhammed Abdulhamid en-Numeysi, Dâru'lKutubi'l-İlmiyye, Beyrut 1999, s. 49.

14 İbn Hişam, age, II, s. 66.

${ }^{15}$ Bedevi Arapların küfürde inatçı tavırları hususunda bkz. et-Tevbe, 9/97.

16 es-Semhûdî, Vefâ, C. I, s. 173

${ }^{17}$ İbn Hişam, age, C. II, s. 70.
} 
Evs-Hazrec, daveti kabul cesareti kadar, ilk andan itibaren sergiledikleri korkusuz tavırları ile de öne çıkıyorlardı. Örneğin, akabe görüşmelerinde 1srarla harp ehli olduklarını dile getirmişlerdir. ${ }^{18} \mathrm{~Hz}$. Peygamber'in akabede kendileriyle gizlice görüşme talebinin en büyük faydası Evs-Hazrecedir. Çünkü buraya müşrik akrabalarıyla birlikte gelmişlerdi. Görüşmenin gizli yapılmasına rağmen, Kureyş'in soruşturmaları neticesinde bu durum EvsHazreç arasında Müslüman-Müşrik paydalarında muhtemel bir çatışmaya sebep olabilirdi. Ensar, Hz. Peygamber'le biatlaşırken anlık bir hevesle davranmamış, aralarından bazı lider şahıslar, biatin mahiyeti ve riskleri hususunda dikkat çekici konuşmalar yapmışlardır. İslam'ı himayenin başlıca riskini Abbas b. Ubâde b. Nadle "kızıl ve siyahla savaş olarak" tanımlamıştır. ${ }^{19} \mathrm{Bu}$ tanımlama, önlerine çıkacak tek engelin Kureyş olmayacağını, bilakis vassal Arap idareleriyle Arap yarımadasına nüfuz eden yarımada dışındaki yönetimlerle de mücadele içinde olabileceklerini gösterir.

\section{Ensar Kimliğini Oluşturan Etkenler}

Hz. Peygamber, Mekke dışına yönelik tebliğ çalışmalarını sürdürürken, özellikle dokunulmazlığın olduğu hac mevsiminde, farklı zamanlarda Medineli hacılarla görüşmeler gerçekleştirmiştir. Medine içindeki siyasal çatışmaların yoğunluğu ilk görüşmelerdeki tebliğin başarısını engellemiş̧ir. Ancak risaletin 10. ve 11. yıllarında Hz. Peygamber bu defa Hazrec kabilesiyle görüşme yapmıştır. Bunda hedefine ulaşan Hz. Peygamber, muhataplarıyla art arda 2 yıllık görüşme ve biatler yapmış ve İslam Tarihi'nde yeni bir dönem başlamıştır.

Kabile içi çatışmaların Evs-Hazrec'de meydana getirdiği olumsuzlukların, İlahi yardımın, resulün çaba ve uygulamalarının ve Ensar'ın cesaret dolu çabalarının Ensar kimliğini oluşturan nedenler olduğunu düşünmekteyiz. Evs-Hazrec'in Ensar olmasını sağlayan nedenler, aralarında İslam'ın yayılma hızı hususunda da etkili olmuştur. ${ }^{20}$ Örneğin Abdüleşheloğulları lideri Sad b. Muaz ve Useyd b. Hudayr'ın, İslam'ın Medine'de yayılmasını engellemek için çaba sarf edecekken bir anda Müslüman olmalarn, ${ }^{21}$ sadece bireysel tercih ve lider faktörü ile açılanabilecek durumlar değildir. Şimdi bu etkenleri sırasıyla inceleyebiliriz.

\section{Kabilevi Çatışma}

Cahiliye döneminde Arap yarımadasında kabile düzeninde yaşayan Arapların kendi aralarında yaptıkları savaşlar Eyyâmu'l-Arab olarak adlandırılır. ${ }^{22}$ Başta Medine olmak üzere, birçok yerde yapılan bu kabile savaşlarında çok sıradan nedenler görmek mümkündür. Hatta bazen bu iç harpler zaten önemsiz olan sebepleri unutturacak bir nitelik taşırdı. ${ }^{23}$ Örneğin Benî Bekir ve Benî Tağlib arasında cereyan eden ve yaklaşık kırk yıl süren Besûs harbinin nedeni bir dişi deveydi. ${ }^{24}$ Keza Abs ve Zibyan arasında da at yarışı yüzünden savaşlar cereyan etmişti. $^{25}$ Nitekim Evs-Hazrec de kendi aralarında, irili ufaklı bir sürü savaş yapmış olup ${ }^{26}$ İslam davetiyle karşılaştığında yaklaşık 120 yıllık bir iç savaşın yorgunluğu içindeydi. ${ }^{27}$

\footnotetext{
${ }^{18}$ İbn Hişam, es-Sîre, C. II, s. 85.

${ }^{19}$ İbn Hişam, es-Sîre, C. II, s. 88.

${ }^{20}$ Cevad Ali, el-Mufassal fí Tarihi'l-Arab Kable'l-İslam, C. IV, y.y.,1993, s. 132. Cevad Ali, Medine'nin mümbit toprağı ve su kaynaklarıyla dolu olmasının halkını yumuşak tabiatlı ve gönlü açık hale getirdiğini söyler. Ancak bu gibi yorumlar muhtemelen Mekke'ye kıyasla söylenmektedir. Yoksa aynı durumun bir sayfiye durumunda olan ancak Hz. Peygamber'e olumsuz cevap veren Taif için söylenmesi mümkün değildir.

${ }^{21}$ Süheyli, age, C. II, s. 258.

${ }^{22}$ Mehmet Ali Kapar, "Eyyâmu'l-Arab”, DİA, C. XII, İstanbul, 1995, s. 14-16.

${ }^{23}$ Muhammed Surûr Zeynel Abidin, Dirasât fî's-Sîreti'n-Nebeviyye, Dâru'l-Erkam, Birmingham 1988, s. 21.

${ }^{24}$ Şihabuddin Ahmed b. Abdülvehhab en-Nüveyri, Nihayetu'l-Ereb Fi Fununi'l-Edeb, C. XV, thk. Müfid Kumeyha, Daru'l-Kutubi'l-İlmiyye, Beyrut 2004, 304.

${ }^{25}$ İbn Hişam, age, I, 305-306; İbn Abdirabbih el-Endelusi, el-ikkdu'l-Ferid, C. VI, thk. Abdülmecid et-Terhini, Daru'l-Kutubil İlmiyye, Beyrut 1983, s. 18-19.
} 
Ma'rib seddinin yıkılışı nedeniyle Amr b. Âmir b. Hârise b. Sa'lebeoğulları, Güney Arabistan'dan kuzeye doğru göçmüşlerdir. ${ }^{28}$ Bunların Evs-Hazrec kolu, yurt olarak kendilerine Medine'yi seçseler de burada huzuru bulmaları kolay olmamıştır. İlk etapta Medine'nin yerlisi olan Yahudilerle uzun süre çatışmışlar yaşamışlar, Medine'nin hâkimiyeti ellerine geçtikten sonra bu defa da kendi aralarında çatışma ve savaş safhası başlamıştır. Aralarında başlayan mücadelelerde, üstünlük sürekli el değiştirmiştir. Bunların kimisi ufak çaplı ve kabile kolları arasındaki çatışmalar, kimisi ise uzun zaman devam edecek nitelikte, tüm kabile kollarının iştirak ettiği ve önemli kayıpların yaşandığı geniş kapsamlı idi. Bunlardan Semîr, ${ }^{29} \mathrm{Ka}$ ‘b b. Amr el-Mâzinî, ${ }^{30}$ Serâre, ${ }^{31}$ Rabîu'z-Zaferî ve Farîğ ${ }^{32}$ bireysel nedenlerden ötürü meydana gelen çatışmalardır. Bazen de Husayn b. Eslet'te olduğu gibi bireysel bir çatışma, bir intikam savaşına evrilmiş ve tüm Evs-Hazrec kolları iç savaşa tutuşmuştur. ${ }^{33}$ Tüm bu sayılan iç savaşlarda savaşı başlatan bireysel çatışmalar, genelde karşı tarafın caydırıcı gücü nedeniyle ödenen diyetler ardından sonlanmıştır. Ancak Evs-Hazrec arasında bazen misafirleri sebebiyle bile büyük ölçekli savaşlar vuku bulmuştur. Örneğin Hâtıb savaşı bunlardan biridir. Hâtıb, Evs'e misafir olan Salebeoğullarından bir şahsın öldürülmesi ile başlamıştır. Beni Hars b. Hazrecoğullarının saldırısı ile başlayan savaş, adını, öldürülen misafirin ev sahibi olan Hatıb'dan alır. Bu savaş için komşu kabilelerin sulh için yaptığı girişimler sonuçsuz kalmış ve savaş Hazrec'in zaferiyle sonuçlanmıştır. ${ }^{34} \mathrm{Bu}$ savaşın artçı iç savaşları da olmuştur. Bunlardan birisi Rabî‘ savaşıdır. Rabi‘ denen mevkide yapılan bu savaşta Evs hezimete uğramıştır. Bir diğer artçı vaka da Bakî‘dir. İki taraf, "Bakî'u'l-Ğarkad" denilen yerde tekrar karş1laşmış, burada Evs galip gelse de neticede anlaşmaya oturulmuş, ancak diyet olarak Hazrec tarafından verilen üç kişi Evs kabilesi tarafından öldürülmüştür. ${ }^{35}$ Bunun üzerine Hazrecliler savaş için hazırlanmış ve "Hadâlk" denilen yerde Evsliler ile birbirlerini yok edecek noktaya gelmiştir. Evslilerin kendilerine rehin olarak bırakılan üç genci öldürmelerinden dolayı bu vakaya "Ficâr" adı verilmiştir. ${ }^{36}$ Evs-Hazrec mücadelesinin eyyamu'l-arap içindeki yeri çatışma kültürü açısından benzerlik taşısa da sıra dışı bir durum etken olsa da misafirler veya civar hakkı edinenler için bile kardeş kabileler savaşmaktaydı.

Evs ve Hazrec kabileleri bu defa "Mudarrıs" ve "Muabbis" denilen iki duvarın yanında karşıllaşmıș, şiddetli bir şekilde günlerce savaștıktan sonra Evsliler hezimete uğrayıp evlerine ve kalelerine çekilmiştir. Sonra Amr b. Avfoğulları ile Evs kabilesinden Evs Menâtoğulları bir araya gelip Hazrec kabilesiyle sulh anlaşması yapmak istemiş, fakat Evs kabilesinden Abduleşheloğulları ile Zaferoğulları intikam peşinde oldukları için sulha yanaşmamıştır. Bu arada Amr b. Avfoğulları ile Evs Menâtoğullarının sulh teklifini bir firsat bilen Hazrec kabilesi, onlara karşı baskılarını artırmıştır. Artık Medine, söz konusu iç savaşlar nedeniyle

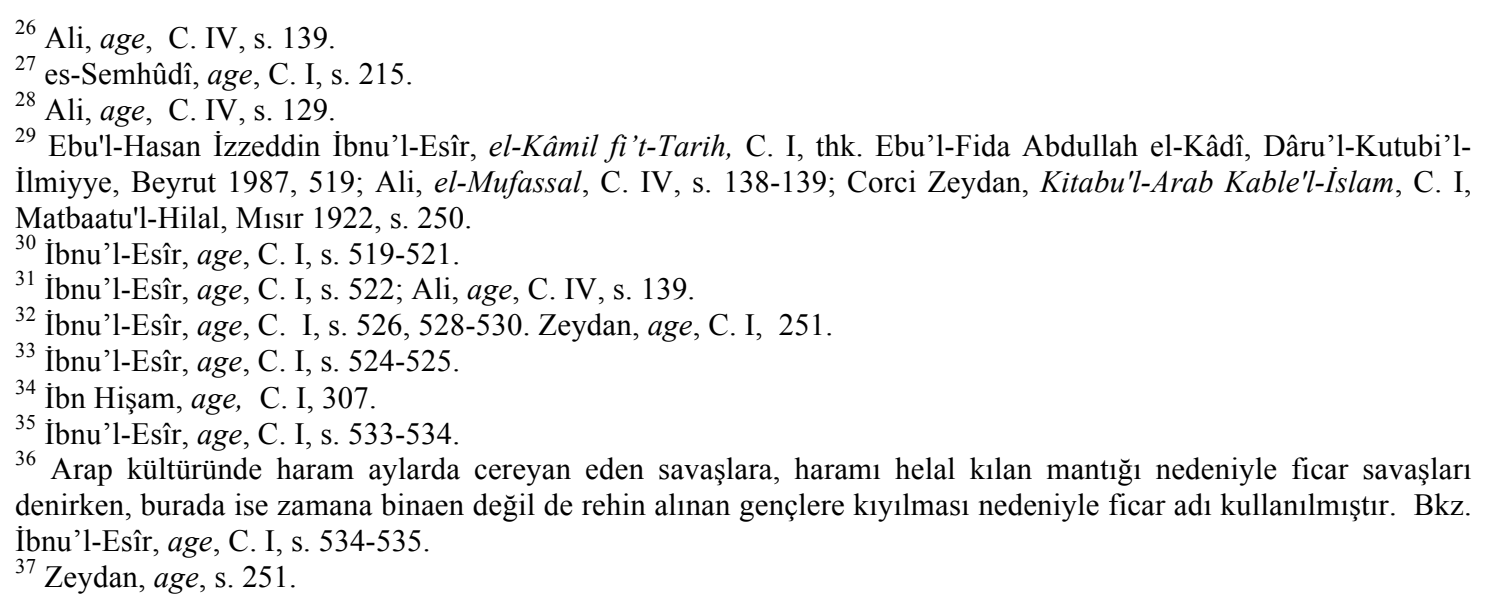


neredeyse yaşanmaz hale gelmiştir. Çünkü çatışmaların yoğunlaşması ile Evs kabilesinden savaşı sürdüren Abduleşheloğulları ile Zaferoğulları haricindeki diğer kollar, Medine'den göç etmeyi bile düşünmüşlerdir. Bir kısır döngü içerisinde devam eden bu iç savaşlar, zamanla Medine içinde daimi bir hakimiyet kurmak için kabileleri dışarıdan destek arama yoluna sevk etmiştir. Örneğin, Muabbis ve Mudarrıs vakasında büyük bir hezimet yaşayan Evs kabilesi mensupları, umre bahanesiyle Mekke'ye gelerek Kureyşle savaş ittifakı yapmışsa da bu ittifak Ebû Cehilin zekice bir manevrası sayesinde iptal edilmiştir. ${ }^{38}$ Aslında bu tür manevralar çatışmaların tüm yarımadaya yayılmasını engellemesi yönüyle hayli önemlidir. Çünkü özellikle Kureyş, ticari faaliyetleri ve Kâbe'nin hadimi olması yönüyle çatışmanın tarafı olmama gibi bir siyaset gütmekteydi. Ancak kendi içinde ilânihaye devam edecek gibi duran iç harpler, Evs-Hazrec'i adeta iç savaşla özdeş hale getirmiştir. İşte Evsli heyetin Mekke'deki bu ittifak arayışı esnasında Hz. Peygamber kendilerini İslam'a çağırmıştır. Ancak Hazrec'e karşı Kureyş'ten destek aramaya geldikleri için, Kureyş'in adeta düşman kesildiği Hz. Muhammed'in davetine icabet etmeleri beklenemezdi. Hatta bu karşılaşmada Enes b. Rafi', Hz. Peygamber'e karşı Kureyş'in tavrını bildiği için: “Çok garip; düşmana karşı Kureyş’ten destek bulmaya geldik, Kureyş'i de düşman edinerek mi dönelim?” diye cevap vermiştir. ${ }^{39}$

Medine'de Yahudilerle verdikleri egemenlik mücadeleleri ardından hâkimiyeti ele alan Beni Kayle, artık kendi aralarında savaşmak için bazı Yahudi kabilelerle de ittifak arayışına girmiştir. Evs'in Yahudi Nadr ve Kureyzaoğullarına ittifak teklifi Hazrec tarafından duyulunca hazrecin savaş ilanı gecikmedi. Muhtemel ittifaka karşı savaşmama garantisi için rehin alma yoluna başvuran Hazrecliler, Nadr ve Kurayzaoğullarından kırk genci rehin aldı. Rehine garantisine rağmen savaşa tutuşan Yahudiler nedeniyle Hazrec elindeki bazı rehineleri öldürdü. Çünkü Hazrec Yahudi kabilelerin ahde vefa göstermedikleri kanaatindeydi. Nitekim bu olaya, daha önce de yaşanan bir rehine öldürme olayı nedeniyle "İkinci Ficâr Vakası" adı verilmiştir. ${ }^{40}$

Evs-Hazrec'in iç savaşlarda zor zamanlarda başvurduğu yollardan birisi, müttefik kabile arayışı idi. Daha önce Kureyşle ittifak arayışında başarısız olan ve Yahudilerle ittifak kuran ve ikinci ficarda tüm Yahudi kabileleriyle müttefik olan Evs'e karşı Hazrec, Eşcâ ile Cüheyne kabilelerinin desteğini alınca, Evs de müttefiki Müzeyne'nin desteğine başvurdu. ${ }^{41}$ Dolayısıyla, bu durum çatışmanın bir iç savaştan çıkıp bölgesel bir hale evrilmesi demekti. Zaten bu ölçekte büyüyen ittifaklar nedeniyle cereyan eden savaş Medine tarihinde en büyük ve en uzun soluklusu oldu. Bu kadar geniş̧ çaplı katılım, savaşın muvakkat üstünlüklere sahne olmasına sebep olsa da neticede Hazrec mağlup oldu. En büyük ve en yıkıcı olan Buas denen bu savaş bile Evs-Hazrec mücadelesinin, bir inat uğruna sürdürüldüğünün açık bir örneğidir. Şöyle ki, Buas'ta galip gelen taraf Evs olmasına rağmen, savaş sonunda Evs'in müttefik kabileleri Hazrec'e ait eşyaları yağmalamış ancak Evs bu sürece dahil olmamıştır. Bunda en büyük neden, yıllarca savaşıyor olmalarına rağmen Hazrec'in kendilerine kardeş kabile oldukları yönündeki hatırlatma ve telkinleridir. ${ }^{42}$

Buâs savaşı ardından, bu defa Mekke'ye hac için giden mağlup taraf Hazrec, ittifak arayışı içinde olmamıştır. Bunun temel nedeni, Hazrecin bu kısır döngüden usanmış olmasıdır. Hazrecli heyetin miladi 620 yılında yaptıkları bu hac ziyareti, planlı olmasa da Medine'nin siyasi ve sosyo-kültürel yapısını değiştirecek bir duruma yol açmıştır. Çünkü aralarındaki en şiddetli savaş olan Buâs harbinin yıkıcılığı da o ölçüde olmuştur. Hz. Aişe'den gelen bir

\footnotetext{
${ }^{38}$ İbnu'l-Esîr, age, C. I, s. 535-536.

${ }^{39}$ Belâzurî, age, C. I, s. 238.

${ }^{40}$ Evs-Hazrec arasında cereyan eden ikinci ficar vakası için bkz. İbnu'l-Esîr, age, C. I, s. 533-534.

${ }^{41}$ Ali, age, C. IV, s. 139.

${ }^{42}$ İbnu'l-Esîr, age, C. I, s. 538.
} 
rivayet Buâs'ın bir firsat oluşturduğu şeklindedir. Bu tespit, Buâs'ta ölen ve muhtemelen İslam'a karşı çıkacak kabile liderlerinin ölümü ${ }^{43}$ şeklinde anlaşılmamalıdır. Çünkü Buâs harbindeki büyük kayıplar sebebiyle geriye Evs'ten Ebû Amir, Hazrec'ten ise Abdullah b. Übey gibi liderler kalmıştır. Bu iki şahıs da İslam'a azılı düşmanlık etmiş, birisi nifak üzere ölürken diğeri Medine'yi terk ederek müşrikler safında İslam'a savaş açmıştır. Dolayısıyla Medine'de İslam'a düşmanlık edebilecek lider kesimin Buâs'ta ölmüş olması, İslam için bir fırsat olarak görülmemelidir. Neticede Evs-Hazrec arasında yılların oluşturduğu bir düşmanlık söz konusudur ki Buâs'tan sonraki durum için bile yapılan "soğuk savaş"44 tanımlaması oldukça yerindedir. Ayrıca bazı kabile liderlerinin İslam'a yaklaşımı yine de mesafelidir. ${ }^{45}$

Buâs öncesinde ve sonrasında yapılan tebliğler, sonuç açısından birbirlerinden iyi ayırt edilmelidir. Öncesinde Mekke'ye gelen Evsliler davete icabet etmezken, sonrasinda gelen Hazrecliler, İslam'ı kabul etmiştir. O halde, iç harbin son halkası olan Buâs ile Medineli Araplar için hayat tahammül edilemez bir noktaya varmıştır demek mümkündür. ${ }^{46}$ İşte $\mathrm{Hz}$. Aişe'nin Buas savaşını bir fırsat olarak değerlendirmesini bu noktadan ele almak gerekir.

Hz. Peygamberle karşlaşma anlarından itibaren ise Evs-Hazrec'in mücadelesi bu defa savaştan fazilet yarışına doğru dönüşmüştür diyebiliriz. Bunun en büyük göstergesi, İslamla ilk tanışma ve ilk Müslümanlık hususunda aktarılan rivayetlerdir. Örneğin Evs kabilesinin Amr b. Avfoğulları kolundan olan Süveyd b. Sâmit, Hz. Peygamber'e iman eden ilk Medineli olarak gösterilir. Kendisi hac ibadeti için geldiği Medine'de okuduğu şiirlerle dikkat çekmiş, ancak resulün kendisine Kuran okumasından da hayli etkilenmiştir. Bu olay Buâs harbinden önce vuku bulmuş olup, bu savaşta ölen Süveyd'in Müslüman olduğu rivayet edilir. ${ }^{47}$ Özellikle İslam'ın Evs-Hazrec tarafından kabulünde Süveyd'in etkili olduğu yönündeki yorumlara rastlamak mümkündür. ${ }^{48}$ İkinci olay ise yine Evs'ten bir şahıs olan Iyas b. Muâz'la ilgilidir. Hz. Peygamber kendilerine İslam'ı tebliğ edince, Iyas'ın olumlu yaklaşımı Ebû'l-Hayser Enes b. Rafi' tarafindan sert tepki görmüş ve topluluk, İslam'1 kabul etmeden Medine'ye geri dönmüştür. Kısa süre sonra Iyas'1n tekbirler ve tehliller getirerek ${ }^{49}$ Müslüman olarak öldüğü rivayet edilmektedir. ${ }^{50}$ Müslüman olduğu öne sürülen her iki şahsın da Evsli olması, EvsHazrec arasında İslam'da öncelik noktasında bir yarış anlamına gelebilir. Ayrıca ileride görüleceği üzere İslam'ı ilk kabul edenlerin hepsinin Hazrecli olması, bunu düşündüren bir durumdur. Fakat bir kahraman ve şair olmasına rağmen, Süveyd'in İslam'1 Medine'de yayma hususunda herhangi bir çalışma yapmamış olması şaşırtıcıdır. Halbuki İslam'ı kabul eden Hazreclilerin Medine'ye döner dönmez yaptıkları tebliğ faaliyeti o derece etkili olmuştur ki hemen hemen her evde Hz. Peygamber konuşulmuştur. ${ }^{51}$

Habeşistan hicreti yarımada dışında acem diyarına yapılmıştı. Bu hicret, yarımadanın geleneksel bağına her hangi bir zarar vermiyordu. Ancak yarımada içinde başka bir belde de

\footnotetext{
${ }^{43}$ Semhûdî, bu tespitten yola çıkarak Evs-Hazrec'in Buâs'ta hayatını kaybeden liderleri için şöyle der "Onlar İslam'a iman etmeyecek, kibirlenecek, İslam'a girmekten imtina edecek, cahiliyeye sıkı şekilde bağlı ve başkasının emri altına girmeyecek ölçüde kibri ve muhalefetinde aşırı kimselerdi.” Bkz. Semhûdî, age, C. I, s. 218.

${ }^{44}$ W. Montgomery Watt, Muhammad at Medina, Oxford University Press, Great Britain 1956, s. 173.

${ }^{45}$ İbn Hişam, age, C. II, s. 78.

${ }^{46}$ Belâzurî, age, C. I, s. 239.

${ }^{47}$ İbn Hişam, age, C. II, s. 69. İbn Hişam İbn İshak’tan rivayetle aktardığı bu habere karşın yine Sire'de Süveyd b. Samit'in Hatıb savaşında öldürüldüğünü aktarır. Bkz. age, C. I, 307.

${ }^{48}$ Mevlânâ Şiblî Numânî, Son Peygamber Hz. Muhammed, çev. Yusuf Karaca, red. Muharrem Tan, İz Yay., İstanbul 2012, 178.

${ }^{49}$ İbnu'l-Esîr, age, C. I, s. 610.

${ }^{50}$ İbn Hișam, age, C. II, s. 69.

${ }^{51}$ İbn Hişam, age, C. II, s. 73.
} 
olsa, civâr gibi bir himaye türü ile değil de İslam paydası ile himayeyi göze almak, Medine için kabile çatışmasından daha büyük bir yıkımdı. Çünkü Evs-Hazrec, Arap geleneğinde bir ilke imza atıyordu. Ayrıca muhacirler İslam'a girmeyen aile üyelerini de terk ederek dindaşlarına sığınacaklardı. Daha ilginç olanı, yarımadanın iç savaşla boğuşan bu iki kardeş kabilesi sadece kendisini değil yarımadanın sosyo-kültürel yapısını da değiştirecek bir çağrıya ev sahipliği yapacaktı. Dolayısıyla bu denli büyük bir riski göze almak, bitmek bilmeyen ve kabileyi yok olmanın eşiğine taşıyan kabilevi çatışma ortamı nedeniyle olmuştur.

Mekke'de kendilerine yapılan davete cevap veren Evs-Hazrec'in, akabe sürecinde sayısı sürekli artmıştır. Ancak gerek Medine'nin sosyolojik yapısı ve gerekse en büyük savaşlarda Yahudilerin de taraf olmaları bundan sonraki gidişat için yeni kararlar almalarına neden olmuştur. Evs-Hazrec, iç harbin sebeplerinden birinin Yahudi kabileleri olduğunu çok iyi bildiğinden, onlarla olan anlaşmasını akabede bitirme kararı almıştır. Çünkü bu tür ittifaklar, eski halin devamlılığı anlamına gelmekteydi. Akabede bunu dile getirmelerinin sebebi, akabeye muvakkat bir gözle değil, bilakis ciddiyetle bakmalarıdır. Ancak bu hususu dile getiren Ebû Heysem b. Teyyihan'ın "Bizimle bazıları -Yahudiler-arasında bağlar var, biz onları keseceğiz, bu durumda ilerde bu yolda başarılı olursan bizi terk edip kavmine döner misin?" 52 sorusu birliktelik yanında, aslında Ensar karakterinin sürekliliğine de işaret eder. Burada siyasi bir pazarlık değil, bilakis Medine'deki sosyal ve siyasal hayata çekidüzen verme durumu vardır. Çünkü Medine Arapları her ne kadar Yahudilerle siyasal ittifaklar yapmış olsalar da bu ittifaklar genel anlamda müşrik Araplar ve Yahudiler arasında değil, bilakis kabileler arasında yapılmıştır. Ancak akabedeki ittifak farklıdır. Artık Evs-Hazrec, ucu açık bir blok oluşturma yolunda olup, bu da kabile paydasında bir kamplaşmanın bitişi demektir. Bu sözler aslında, bulunan çözümün gelip geçici olmadığının bir ifadesidir. Nitekim ileride Benî Nadir Yahudilerine sürgün haberini ulaştıran Muhammed b. Mesleme, kendisine dostluklarını hatırlatan Yahudilere "Artık kalpler değişti ve İslam -önceki- ahitleri ortadan kaldırdı" ifadesini kullanacaktır. ${ }^{53} \mathrm{Bu}$ duruş, akabede verilen sözün neticesidir.

Hicretle birlikte Medine'de eskiden beri süregelen kabilecilik anlayışının değişmesi artık kaçınılmazdı. Çünkü hicret ederek gelenlerin, kabile paydası üzerinden değil de Müslüman paydası ile gelmesi, Medine'de Mekke'nin fethine kadar muhacir sayısının giderek artmasına, Evs-Hazrec açısından kabilecilik anlayışının bir dönüşüm yaşamasına sebep olmuştur. ${ }^{54}$ Ancak bu durum, kabileciliğin bitirilmesine yönelik bir girişim olarak yorumlanmamalıdır. Çünkü Hz. Peygamber, daha Mekke'de iken Medineli kabilelerden birer temsilci seçmiştir. Bu şahısların görevleri farklı şekilde tanımlanmıştır. Buna göre nakibler kabile ölçeğinde temsilci, ${ }^{55}$ tebliğci, aracı ve haberci ${ }^{56}$ olmak üzere birçok farklı görevle tanımlanmıştır. Hz. Peygamber nakiblere "Siz kavminizden sorumlusunuz... ben de kavmimden sorumluyum" diye tembihte bulunmuştur. Yalnız buradaki temel fark, seçimin tüm kabileler üzerinden değil de İslam'a giren ve ona hizmet edecek kabile üzerinden yapılmış olmasıdır. Dolayısıyla Evs-Hazrec, kabileciliğin yıkıcı sonuçlarından kurtulmanın kabileciliği merkeze koymayan İslamla olabileceğini anlamış ve bir asrı geçen çatışma ortamını, kendileri ve Kureyşli Müslümanlar için bir firsata dönüştürmeye çalışmıştır.

\footnotetext{
52 İbn Hișam, age, C. II, s. 84.

${ }^{53}$ Taberî, Tarihu'r-Rusûl ve'l-Mulukk, C. II, thk. Muhammed Ebû'l-Fazl İbrahim, Dâru'l-Meârif, Kahire, t.y., s. 552.

${ }^{54}$ Adnan Demircan, Nebevi Direniş Hicret, Beyan Yay., İstanbul 2015 age, s. 140.

${ }^{55}$ Hasan, başkanlık yapmak üzere temsilciler seçildiğini söyler. Bkz. İbrahim Hasan Hasan, İslam Tarihi, C. I, çev. İsmail Yiğit, Sadreddin Gümüş, Kayıhan Yay., İstanbul 2011, s. 133; Numani, kabilelerinin ileri gelenlerinden olan bu şahısların İslam'ı kabulünün tüm kabileyi de bağladığını öne sürer. Bkz. Numani, age, s. 179.

${ }^{56}$ Numani, age, s. 180.
} 


\section{2. İlahi Yardım}

Hz. Peygamber'in risaletine engel olan şeylerin bir kısmı, aslında hem hayat garantisi hem de İslam'ı tebliğ için birer firsattı. Bunların başında kabilevî yaşam gelir. Kabile liderlerinin İslam'a olan düşmanlığı, İslam'ın Mekke'de hatta tüm yarımadada yayılmasını engellerken, yine kabile mantığının temelini oluşturan asabiyet, bunun zıddına bir işlev görmüş̧ür. Ebû Cehil, Hz. Muhammed'in peygamberliğiyle, "Ey Abdu Menâfoğulları, bu sizin Peygamberinizdir" diyerek alay edince bir başka müşrik Utbe b. Rabîa kendisine "Bizden niye bir Peygamber ve bir hükümdar olmasın ki?" diye cevap vermiştir. ${ }^{57} \mathrm{Bu}$ diyalog, inanç birliğine karşın kabileler arası mücadele, asabiyet ve kabile şerefi konularına verilecek önemli bir örnektir. Mekke'de İslam'a yönelik muhalefet şirk üzerinden sürdürülmesine rağmen, Arap kültüründe din değil, kabile yapısı üst kimliği oluşturmaktaydı. Dolayısıyla tebliğin bu şartlarda Mekke'de yaklaşık 13 yıl sürmüş olması, aslında ilahi bir yardımdır. Neticede Mekke'deki 13 yıllık risalet süresi boyunca kuşatıcılık açısından din, tam anlamıyla kabile etkeninin önüne geçememiştir. Ancak bundan daha çarpıcı olanı ise yine kabileciliğin şekil verdiği Arap kültürünü tamamen altüst edercesine Medineli Evs-Hazrec'in Ensar rolünü üstlenmesidir. Çünkü bu tercih, yarımadada kabile yapısına alternatif bir sosyal değişim ve dönüşüm demektir. Bu da kabilenin yerine inancın üst kimlik olarak kabul edilmesidir.

Hz. Peygamber'in Mekke'de tebliğ çalışmalarına devam etmesi için yine şirk kültürünün dini kabullerinden birisi olan ve aslında ilahi yardımdan sayılabilecek haram ayları beklemekten başka çaresi yoktur. Çünkü Ebû Talib'in ölümünden sonra bir diğer amcası Ebû Leheb, kabile kültürünün ruhu demek olan asabiyeti hiçe sayarak onu sahiplenmediği gibi, hac için gelen kabilelere yönelik, onun aleyhinde adeta lobi faaliyetinde bulunmuştur. ${ }^{58} \mathrm{~Hz}$. Peygamber bu maddi ve manevi baskı ve dışlanmışlık ortamında bıkmadan tebliğini sürdürmüştür ve bu çabaları, Medineli Evs-Hazrec'in olumlu cevabı ile meyvesini vermiştir. Tebliğin Mekke dışında sahiplenilmesi sayesinde; müşrik, birbirini kıran, kardeşliği unutmuş bir toplumun nasıl hidayete ve birlik-bütünlüğe kavuștuğunu bizlere Kuran net bir șekilde anlatmaktadır. ${ }^{59}$ Kabilelere yönelik tebliğ çalışmalarının Evs-Hazrecle hedefine ulaşması, Siyer kaynaklarında ilahi bir lütuf olarak tanımlanır. Örneğin İbn $\mathrm{Sa}^{\prime} \mathrm{d}$ bu durumu "Nihayet Allah dinini desteklemek, elçisine yardım etmek ve vaadini yerine getirmek istedi. Bu amaçla Allah, elçisine verdiği değerden dolayı onu Ensar'dan bir grubun semtine sevk etti ${ }^{\prime 60}$ şeklinde yorumlamıştır. İbn İshak'tan gelen bir rivayette ise "Allah dininin yayılmasını, nebisine yardım etmeyi ve vaadini gerçekleştirmeyi istediğinde peygamber hac mevsiminde Ensar'dan bir gurupla karşılaştı." ${ }^{61}$ Bir başka rivayette ise "Allah nimetinden onlara dilediğini vermek, nebisine yardım etmek, İslam'ı ve Müslümanları güçlendirmek, şirki ve ehlini zelil kılmak istediğinde Ensar Resulle akabede ahitlești" ${ }^{62}$ ifadesi yer almaktadır.

Hz. Peygamberin soyu, dede tarafından Hazrec'in Benî Neccar koluna dayanır. ${ }^{63} \mathrm{~Hz}$. Peygamberin babası, dayıları Benî Neccar'ın yanında, annesi Âmine de bu akrabalık için Medine'ye yaptığı ziyaret dönüşü Medine'nin Ebva köyünde vefat etmiştir. ${ }^{64}$ İlahi yardımla

\footnotetext{
${ }^{57}$ İbnu'l-Esîr, age, C. I, s. 608.

${ }^{58}$ İbn Hișam, age, C. II, s. 65.

59 "Siz bir ateş çukurunun tam kenarındayken, oradan sizi o kurtarmıştı." Ayetinin tefsiri için bkz. Ebû Cafer Muhammed et-Taberî, Camiu'l-Beyân An Te'vîli Ayyi'l-Kuran, C. V, thk. Abdullah b. Abdulmuhsin et-Turki, Dâru Hicr, Cize 2001, s. 657.

${ }^{60}$ İbn Sa'd, age, C. I, s. 185.

${ }^{61}$ İbn Hişam, age, C. II, s. 70.

${ }^{62}$ İbn Hişam, age, C. II, s. 81.

${ }^{63}$ İbn Sa'd, age, C. I, s. 79.

${ }^{64}$ İbn Sa'd, age, C. I, s. 79, 95.
} 
açıklanabilecek olan akrabalık bağı, muhtemelen tebliğde bir ülfet oluşturmak amaciyla $\mathrm{Hz}$. peygamber tarafından dile getirilmiştir. ${ }^{65}$ Ancak burada Evs koluyla yapılan önceki görüşmelerde bu bağdan bahsedilmemiş olması bir şeyi değiştirmez. Çünkü bu esnada zaten Evs kabilesi kardeş kabile olan Hazrec'e karşı savaş için ittifak arayışındadır. Dolayısıyla kendilerine bir akrabalık bağından bahsedilse bile bu durum bir ülfet teşkil etmeyecekti.

Akabe sözleşmeleri ile İslam'ın ilk faydası Medine içine olmuştur. Burada İslam'a yardım etmeyi taahhüt eden Evs-Hazrec, sadece muhacirlere olan yaklaşımı üzerinden değil, kendi aralarındaki uyum, insicam ve hayırda yarışma yönüyle de bir değişim yaşamıştır. EvsHazrec'in kendi içinde eski kavgacı ve savaşçı geleneklerini sürdürmeyişinin sebebi, İslam'1 kabulleridir. Zaten kendi içlerinde bir dostluk kuramadan muhacirlere kucak açmaları da mümkün değildi. Nitekim Hazrecli hacılar, Hz. Peygamberle ilk karşıllaştı̆̆ında içinde bulundukları durumun vahametini özetlercesine şöyle demişlerdir: "Geride öyle bir kabile bıraktık ki içinde bu denli düşmanlık ve kötü durum olan başka bir topluluk bilmiyoruz. Umarız Allah senin sayende onları bir araya getirir, senden duyduklarımızı onlara aktaracağız ve onları senin mesajına davet edeceğiz, bu kabul ettiğimiz dini onlara arz edeceğiz, eğer Allah onları bu din üzere toplarsa senden daha güçlüsü yoktur." ${ }^{66} \mathrm{Bu}$ ifadede, çağrının kendisine, yani ilahi lutufa bir vurgu vardır. "Şayet yeryüzündeki şeyleri tümüyle harcasaydın, sen onların kalplerini uzlaştıramazdın. Fakat Allah onların arasını uzlaştırdı. Şüphesiz O, mutlak güç sahibidir, hüküm ve hikmet sahibidir." ${ }^{97}$ ayeti, Evs-Hazrec'in İslam öncesi durumlarına etraflıca değinmese de Hazrec'in yakındığı bu düşmanlık boyutuna işaret etmektedir. ${ }^{68}$ Aslında bu tespit, kendilerinin hiçbir metâya değer vermediklerinin de ifadesidir. Dolayısıyla bu anlayıştaki insanların ellerinde olan maddiyatı yardım için harcamalarından daha tabii bir şey olamaz. Hazrec kabilesi, Hz. Peygamberle görüşmelerinde bu tespit ve yakınmaları ile aslında, kısmen bir iç huzur ve sükûn arayışında olduklarını itiraf etmekteydi. Çünkü iç savaş, kendilerine kısa süreli bir üstünlük ve zaferden başka hiç bir şey sağlamıyordu.

Kuran'da Ensar'ın nitelikleri anlatılırken onların muhacirlere yönelik koşulsuz sevgisine işaret edilir. ${ }^{69}$ İşte İslam sayesinde kendi içlerinde meydana gelen ülfet, Evs-Hazrecle sınırlı kalmamıştır. Kendi aralarında amansız bir savaş içinde olan bu iki kabilenin bu denli bir koşulsuz sevgisi, dinleri için kendilerine sığınan muhacirlere de yönelik olup, bu da bir ilahi yardımdir.

Medine'de kabile liderlerinin hızla ikna edilmesi veya ikna olması sonrasında İslam daveti ciddi bir ilgi görmüş ve hicret öncesinde 13 yıllık Mekke süresince ulaşılan Müslüman sayısına Medine'de aşılmıştır. Böylece Evs-Hazrec arasında var olan kabilevi rekabet, hicretle birlikte devam etse de artık boyut değiştirmiş ve bu defa İslam yolunda hayırda yarış şekline dönüşmüştür. Müslüman olmalarına rağmen birbirinin ardında namaz kılmayan Evs-Hazrec'in, Mus'ab b. Umeyr'in imamlığ 1 ile aynı safta toplanabilmesi, kalplerin yavaş yavaş birbirine karşı yumuşadığının göstergesi olup, bu da bir ilahi yardım ile gerçekleşmiştir. ${ }^{70}$

İbn İshak'ın aktardığ Hazreclilere yaklaşıp Yahudi mevalisinden olup olmadıklarını sormuştur. Bir rivayete göre, bu

\footnotetext{
${ }^{65}$ Muhammed b. Hasan İbn Zebâle, Ahbâru'l-Medine, Merkezu Buhûs ve Dirâsâti'l-Medineti'l-Münevvere, Medine 2003, s. 69.

${ }^{66}$ İbn Hişam, age, C. II, s. 70-71.

${ }^{67}$ el-Enfâl, 8/63.

${ }^{68}$ et-Taberî, Camiu'l-Beyân, C. XI, s. 256-259.

${ }^{69}$ Haşr suresi 59/9.

70 "Şayet yeryüzündeki şeyleri tümüyle harcasaydın, sen yine de onların kalplerini uzlaştıramazdın. Fakat Allah onların arasını uzlaştırdı. Şüphesiz o mutlak güç sahibi ve hakimdir.” Enfal 8/63. ayetin tefsiri için bkz. Taberî, age, C. XI, s. 256-259.
} 
esnada tebliğ talebini kabul eden Hazrec'in, hidayete yönelme sebeplerinden birisi de Yahudi kabilesinin etkisidir. ${ }^{71}$ Medine'ye Araplardan önce yerleşmiş olan Yahudi kabileleri ticaret ve ziraatta oldukça mahir, genelde içlerine kapalı, ancak yanı başlarında yaşayan müşrik Araplarla da ilişki içindelerdi. Hatta Yahudilerle bir arada yaşıyor olmaları, Allah'ın bir lutfu olarak tarif edilir. ${ }^{72}$ Bazı çalışmalarda putperestlik inançlarını zayıflamasında, nübüvveti anlamada ve davete icabette Yahudi kültürünün etkili olduğu söylenmektedir. ${ }^{73}$ Ancak bu tarz söylem ve tespitler, Hz. Peygamber'in tebliğdeki başarısını da önemsiz bir duruma indirgemektedir. Keza böyle bir yorum yapılması durumunda, İslam'1 kabul eden Hazrec kabilesinden önce Evsle yapılan görüşmede, bahsedilen Yahudi etkisinin olmaması şaşırtıcıdır. Kaynaklarda yine Hazrec kabilesinin İslam'ı kabul etmesinin nedeni olarak Yahudilerin EvsHazrec'i yeni gelecek Peygamber sayesinde mağlup etme yönündeki tehditleri gösterilir. Ancak Hazreclilerin sırf bu tehditle Hz. Peygamber'e iman etmiş olmaları da mümkün değildir. Çünkü semavi din mensubu olan Yahudiler yaklaşık bi‘setin 11. yılına kadar Hz. Peygamberle herhangi bir iletişime henüz geçmemiştir. ${ }^{74}$ Ayrıca Mekke döneminde Habeşistan'dan bir Hıristiyan heyetinin gelip İslam'a girmiş ${ }^{75}$ olmasına rağmen, Medine'den bireysel ya da toplu, herhangi bir ziyaretin gerçekleşmemesi manidardır. Bu yöndeki bir değerlendirme, muhtemelen son iç savaş olan Buâs harbinde Hazrec'in mağlup olması nedeniyle yapılmış olmalıdır. Keza aynı delil açısından bakılınca, Buâs harbinden önce Mekke'de kendilerine tebliğde bulunulan Evs kabilesi mensuplarının İslam'a girmesi gerekirdi. Çünkü Evs kabilesinin, Benî Kureyza ve Benî Nadîr kabileleri ile müttefikken böyle bir bilgiye rağmen İslam'ı tercih etmemeleri düşünülemez. Ayrıca Yahudiler açısından bakacak olursak, onların Evs'e yönelik bu yönde bir tehdidi makul değildir. Çünkü Buas harbinde Evsle ittifak içine girerek Hazreci mağlup etmişlerdir.

İlahi yardım, Ensar'ın takdir ve taltif edilmesini de kapsar. Çünkü Ensar bu yöndeki her ifadeyi, bir övünç ve iftihar vesilesi olarak dile getirmiş ve bu nitelemeler Ensar rolünün devamlılığına neden olmuştur. Nitekim Kuran'da Ensar'1 öven ve onu örnek olarak gösteren pek çok ayet vardır. ${ }^{76} \mathrm{Bu}$ ayetlerin 1şı̆̆ında olsa gerek, Enes b. Malik "Allah bizi Ensar olarak adlandırdı" demiştir. ${ }^{77} \mathrm{Bu}$ taltif, Ensar'ın, görevini adeta ona sarılarak yerine getirmesini sağlamıştır.

İlahi yardım hususunda bir diğer husus ise Evs-Hazrec'in beklentisidir. Hz. Peygamberin tebliğde bulunduğu Amiroğulları'nın söylemleri, Ensar'ın farkını ortaya koyma hususunda hayli önemlidir. Amiroğulları, Hz. Peygamber'den sonra elde edilecek siyasi gücün idaresini talep ederken Evs-Hazrec, İslam'ın başarısı ardından Hz. Peygamberle birlikteliğin devamlılığı garantisini almak istemiştir. Yine Benî Amir, himaye karşıllı̆̆nda yönetim şartı koşarken EvsHazrec ise himaye karşıllı̆̆ cennet vaadine razı olmuştur. ${ }^{78} \mathrm{Bu}$ vaat, ilahi yardımın beklendiğinin bir izahıdır.

\footnotetext{
${ }^{71}$ İbn Hişam, age, C. II, s. 70.

${ }^{72}$ Yusuf b. Abdilberr en-Nemerî, ed-Dürer fi İhtisâri'l-Meğazî ve's-Siyer, thk. Şevki Dayf, Dâru'l-Meârif, Kahire 1991, s. 67.

${ }^{73}$ Hasan, age, C. I, s.126-127.

74 Üstelik Nadr b. el-Hâris ve Ukbe b. Ebî Muayt, Kureyş tarafindan Hz. Muhammed'in risaleti hususunda bilgi almak için Medine'ye gönderilmiştir. Ancak bu görüşme ardından bile Yahudiler Mekke'ye gelmemiştir. Bkz. İbn Hiş̧am, age, C. II, s. 321.

${ }^{75}$ Süheyli, age, C. II, s. 179.

${ }^{76}$ el-Enfâl 8/74, Tevbe 9/100, el-Haşr 59/ 9.

${ }^{77}$ Buharî, Menâkıbu'l-Ensar, 1.

${ }^{78}$ İbn Hişam, age, C. II, s. 89.
} 


\section{Hz. Peygamber'in Cabaları}

Hz. Peygamber, İslam'a davet hususunda belki de en çok Evs-Hazrec kabilesi için çabalamıştır. Kendilerinin içinde bulundukları şartlar gereği İslam'a olan ihtiyaçları ve kendi iç sorunlarına çözüm arayışları gibi birçok husus yanında akrabalık bağları da bunda etkilidir. Medineli hacılardan Evs kabilesine yapılan ilk tebliğ, kabul görmemiştir. İkinci tebliğ ise Hazrec'e yapılmış olup, ilk 6 Müslüman'ın hepsi Hazrec kabilesindendir. Hz. Peygamber ilk görüşme ardından Hazreclilerle aynı yerde bir sonraki yıl görüşmek üzere sözleşmiş ancak Mekke'de Müslümanların yaşadığı baskılara rağmen hicret için ısrarcı olmamıştır. Hz. Peygamber bununla, muhtemelen Hazrecli Müslümanların Medine'de herhangi bir toplumsal baskı yaşamalarının önüne geçmek istemiştir. İlk akabe biatında Evs'ten de Müslümanlar vardır. Evs kabilesinin bu durumda İslam'a meyletmesinin de iyi tahlil edilmesi gerekir. Çünkü İslam'ı ilk kabul eden Hazreclilerle birlikte ikinci görüşmede aralarında husumet olmasına rağmen Evs'ten insanların olması da şaşırtıcıdır. Bunun nedenini aradaki kabile diyaloğunun tamamen kesilmemiş olması yanında Kureyş'in Evs'e verdiği destek sözünden cayması olarak görenler de vardır. ${ }^{79}$ Ancak Buâs harbinde Evs'in galip gelmiş olması böyle bir delili geçersiz kılacağı gibi, Evslilerin sırf Kureyş inadına İslama girmesi makul değildir. Dolayısıyla Evs'ten bu guruba katılanlar bir inat üzere değil, tercih üzere bunu yapmıştır demek mümkündür.

Yapılan ilk biatın içeriği, tamamen Medine'nin sosyal yapısını ilgilendiren hususlardan ibarettir. Bu biatın savaştan âri olduğunun bir ifadesi de kadınlar biatı olarak adlandırılmış olmasıdır. Biatın şartları: şirk, hırsızlık, zina, çocuk katli, iftiranın yasaklanması ve iyilik hususunda elden gelen çabanın gösterilmesinden ibaretti. ${ }^{80} \mathrm{Bu}$ şartların yerine getirilmeleri durumunda Hz. Peygamber kendilerine ödül olarak cenneti vaat etmiştir. O halde bundan çıkarılabilecek en önemli sonuç; Ensar, İslam'ı yaşamak karşılığında zaten cenneti hak edecektir ve henüz himaye şartına sıra gelmemiştir. Bir diğer önemli husus ise, Hz. Peygamberin bu şartlarla Medine'nin sosyo-kültürel yapısını düzeltmeyi hedeflemiş olmasıdır. Çünkü bu zamana kadar şirk ve kabilecilik kültürünün sonuçları sebebiyle kendisini yok etme noktasına getiren Medine Araplarının bir sosyal dönüşüme ihtiyaçları vardı. Böylece, şirkten uzak durarak onun bir getirisi olan, çocukları diri diri gömmek yasaklanmakta, keza iki kabilenin çatışmasına sebep olabilecek hırsılık, iftira ve zina gibi kötülüklerin sonlandırılmasıyla da çatışma ortamının bitirilmesi hedeflenmekteydi. Bu dönüşümü hızlı bir şekilde sağlamak amacıyla da Hz. Peygamber Mus'ab b. Umeyr'i bir temsilci olarak Medine'ye göndermiştir. Mus 'ab'in, Medine'de Kuran okumak, İslam'ı öğretmek ve Medineli Müslümanları dinde fakih kılmak gibi görevleri olsa da Kuran'ı kendilerine sık sık okuması sebebiyle kendisi “okuyucu" olarak şöhret bulmuştur. ${ }^{81}$ Böylece İslam'ın en büyük faydalarından birisi olan toplum olma/bir ve bütün olma anlayışı, Musab b. Umeyr'le Medine'de gerçekleşmiştir. Çünkü artık Evs-Hazrec onunla birlikte cemaatle namaz kılmaya başlamıştır. Mus'ab'ın imamlık görevi, Evs-Hazrec'in tarafsız birisi önderliğinde bir safta toplanması şeklinde anlaşılabileceği gibi, henüz yeni Müslüman olmuş Medinelilerin yetersizlikleri nedeniyle namazlarda bir muhacire tabi olmaları şeklinde de düşünülebilir. ${ }^{82} \mathrm{Her}$ iki ihtimalde de Evs-Hazrec'in kaynaştırılması, eğitilmesi ve Muhacir-Ensar bağının temelinin atılması gibi hedefler vardır.

\footnotetext{
${ }^{79}$ Muhammed Hamidullah, İslam Peygamberi, çev. Mehmet Yazgan, Beyan yay., İstanbul 2011, s. 138.

${ }^{80}$ İbn Hişam, age, C. II, s. 75.

81 İbn Hișam, age, C. II, s. 76.

${ }^{82}$ Martin Lings, Hz. Muhammed 'in Hayatı, çev. Nazife Şişman, İnsan Yay., İstanbul 2012, s. 116.
} 
İkinci akabe biatı ise harp biatı olarak adlandırılır. İlginçtir, bu biatta kadınların da yer almasına karşın, maddelerinde savaştan bahsedilmesi nedeniyle savaş biatı olarak bilinir. Ubâde b. Sâmit'ten gelen bir rivayette, ikinci biatin şartları şu şekildedir: "Sıkıntıda ve ferahta, sevinç ve kederde dinleme ve itaat etmeye, başkasını kendisine tercih etmeye, idarenin ehline verilmesi hususunda tartışmaya girmemeye, her hal ve koşulda doğruyu söylemeye, Allah yolunda kınayanın kınamasından korkmamaya savaş biatiyle biat ettik." ${ }^{23}$ Birinci biatte Medine'nin sosyal yapısı ve dinî hayatı üzerinde düzenlemeler varken, ikincisinde Medine'ye gelecek Muhacirler için yapılacak fedakârlıklar ve en önemlisi de siyasi bir düzen kurulacağı kabul edilmektedir. Burada vurgulanan; itaat, idare, Allah yolunda koşulsuz sebat ve doğruluk gibi hususlar belki de Medine'nin en çok ihtiyaç duyduğu ancak yeni oluşacak Müslüman toplumun sürekliliği için vazgeçilmezdir ve Hz. Peygamber bunun teşekküllünden önce gerekli esasları belirlemiş olmaktadır.

Hz. Peygamber, Medine'de İslam'ın tebliği ve faaliyetlerin takibi için bir takım temsilciler seçmiştir. Bunlar, akabeye katılım sayısına göre 9'u Hazrec 3'ü de Evs'ten olmak üzere 12 kişi olup görevleri ise kendi kabilelerinin sorumluluğunu üstlenmektir. ${ }^{84} \mathrm{~Hz}$. Peygamber bu kararı ile İslam'a hizmetin yanında, kabile gerçeğine ve lider kimliğine saygı duyduğunu ima etmiş, şehrin gerçeklerinden hareketle de bir gidişat belirlenmesini hedeflemiştir.

Hz. Peygamber Medine'ye geldiği andan itibaren Ensar-Muhacir arasındaki dostluğun sürekliliği için Müslümanlar arasında paylaşımı ve infakı öğ̈̈tlemiştir. Hicretten hemen sonra Benî Salim yurdunda verdiği ilk hutbede "Yarım hurmayla bile olsa kendinizi -cehennemateşinden korumaya çalışın, bunu bulamayan, güzel bir söz söylesin ki bu da iyiliğin on katına yani yedi yüze kadar bir mükafatla mükafatlandırılmasıdır" ${ }^{\prime 25}$ diyerek, aslında ziraatla uğraşan Medineli Ensar'a imkan dahilinde infakı, Muhacirlere ise, elinde bulunan tek imkanı olan güzel söz söylemeyi tavsiye etmiştir. Ensar tarafından, mallarının paylaşımı teklif edilse de Resulullah bunu kabul etmemiş ve zirai faaliyetlerden alınacak üründe paylaşımı önermiștir. Müslümanların Benî Nadir kuşatmasından elde ettikleri mallar, savaşsız ele geçtiği için $\mathrm{Hz}$. Peygamber'in tasarrufunda kalmıştır. Hz. Peygamber Ensar'a şu iki teklifi sunmuştur: Malların Ensar-Muhacir arasında taksimi ve var olan durumun devamı, ikincisi ise malların muhacirlere verilmesi ile artık kendi evlerine yerleşmeleri. ${ }^{86}$ Evs-Hazrec'in iki lideri ganimetin muhacirlere verilmesi fikrini kabul etmiş, bunun üzerine Hz. Peygamber'in hayır duasını alan Ensar'dan sadece fakir olan iki kişiye bu mallardan verilmiştir. Nitekim Ensar'ın burada muhacir için yaptığı fedakârlık Kuran'da övülmüştür. ${ }^{87} \mathrm{Bu}$ mallar ile Medine'de yaşamakta olan birçok muhacir zengin olmuştur. ${ }^{88}$ Ensar'ın muhacirlere yaptığı maddi fedakârlıklar nifak güruhunun lideri olan Abdullah İbn Übey tarafından da dile getirilmiş, hatta İbn Übey bu tarz maddi fedakârlıklar yapılmasa muhacirlerin başka bir yere göç edebileceğini söylemiştir. Hâlbuki İbn Übey bu sözleri söylediğinde Ensar, Müreysî gazvesinin dönüş yolundaydı. Yani maddi paylaşım bir kenara Ensar, İslam için hayatını çoktan ortaya koymuştu.

Muhacirlere tanınan mal-mülk olanakları, engin hoşgörü, İslam uğrunda canını feda mantığ1, muhacirlerin artmasına rağmen Ensar'ın -savaşlarda daima ön saflarda yer alarak-

\footnotetext{
${ }^{83}$ İbn Hişam, age, C. II, s. 97.

${ }^{84}$ Demircan, age, s. 81

${ }^{85}$ Takıyyüddin Ahmed el-Makrîzî, Imtâu'l-Esma, C. I, thk. Muhammed Abdülhamid en-Nemîsî, Dâru'l-Kutubi'lİlmiyye, Beyrut 1999, s. 66.

${ }^{86}$ Ebu Abdullah Muhammed b. Ömer el-Vakidî, Kitabu'l-Meğâzî, C. I, ed. Marsden Jones, Oxford University Press, London 1966, s. 379.

${ }^{87}$ el-Haşr 59/9 ayetinin açılklaması için bakınız Vakidî, age, C. I, s. 382.

${ }^{88}$ Vakidî, age, C. I, s. 379-380.
} 
sayıca azalmayı tercih etmesi gibi hususlar, münafık kesimin şaşırdığı ama Ensar hayat tarzı haline getirdiği, yaptığı fedakârlıklardır. Ancak yine de yapılan maddi fedakârlıklar uhuvvet ve Ensar karakterinde öne çıkarılmaması gereken taraflardır. Çünkü Resulullah'ın kardeşlik hukuku, dünya meta1 üzerine değil de, inanç esası ve birliğine dayanıyordu. ${ }^{89} \mathrm{Bu}$ faaliyet, Medine İslam toplumuna aidiyetin bir ifadesidir. Yani Hz. Peygamber, cahiliye asabiyetini evvelemirde uhuvvetle eritmeyi başarmıştır. ${ }^{90}$ Uhuvvetin maddiyat üzerine yapılmadığının bir başka delili de bu uygulamanın sadece mekân ve mal mülk sahibi olan Ensar ile Muhacir arasında değil de bizzat muhacirler arasında da yapılmış olmasıdır. Gerçi Hz. Muhammed ile Hz. Ali arasındaki kardeşlik hususundaki rivayet zayıf olarak nitelenmekle birlikte, ${ }^{91}$ muhacirler arasında bir kardeşlik kurulması rivayeti kaynaklarda mevcuttur. ${ }^{92}$ İbn Kayyım, Ensar ile Muhacirler arasında bir uhuvvetin makul olduğunu, ancak Mekke'de Müslüman olan muhacirler arasında var olan İslam, soy ve yurt kardeşliği sebebiyle yeni bir uhuvvete ihtiyaç duymayacaklarını söyler. ${ }^{93}$ Şüphesiz Mekke döneminde ya da muhacirler arasında bir uhuvvet yapıldığı rivayetinin sadece Belâzurî tarafından, üstelik senedsiz olarak rivayet edilmesinin ${ }^{94}$ bunda payı büyüktür. Keza İbn Kesîr, eğer Mekke'de bir uhuvvet yapılmış ise bunun, manevi bir kardeşleştirmeden ileri geçmediğini söyler. ${ }^{95}$ İbn Kesîr'in bu yorumundan hareketle, maneviyat bağının ilânihaye sürecek bir husus olduğunu ve Ensar kimliğinin de bunun üzerine bina edilmesi gerektiğini söylemek gerekir. Ancak maddiyat odaklı bir kardeșleștirmede zengin Ensar ile fakir Muhacirlerin eşleştirilmesi gerektiği delili ${ }^{96}$ isabetli olmasa gerektir. Çünkü hicretle birlikte malını mülkünü yanında götürebilen $\mathrm{Hz}$. Osman haricinde bütün muhacirler maddi anlamda aynı durumdadır. Mekke döneminde zengin ya da ticaret erbabı olsalar da burada hayata yeniden başlamak zorunda idiler. Dolayısıyla uhuvvet uygulamasında ve Ensar karakterinde maddiyatın ön plana çıkarılması anlayışı gerçeklerden uzaktır. ${ }^{97}$ Maddi paylaşım durumu uhuvvetin bir sonucudur. Uhuvvette, genelde öne çıkarılan husus, maddi paylaşım olarak aktarılsa da aslında öncelenen husus, dinde yardımlaşmaktır. ${ }^{98}$

Malda yardımlaşma hususunda Ensar'dan gelen ilk teklif, hurmalıkların paylaşımı şeklindedir. Ancak Hz. Peygamber bunu kabul etmemiş, muhacirlerin bağ-bahçede çalışması şartıyla üründen pay alma şartını getirmiştir. ${ }^{99} \mathrm{Bu}$ hususta çok âfâki paylaşım haberleri ${ }^{100}$

\footnotetext{
${ }^{89}$ Muhammed er-Ravi, el-Medinetu'l-Munevvere fi Ahdi'r-Risale, Mektebetu'l-Ubeykan, Riyad 2006, s. 162.

${ }^{90}$ Ali Muhammed Sallâbi, es-Sîretu'n-Nebeviyye, Dâru'l-Marife, Beyrut 2012, s. 314.

${ }^{91}$ Ebû'l-Fidâ İmaduddin İsmail b. Ömer İbn Kesîr, el-Bidâye ve'n-Nihâye, C. IV, thk. Abdullah b. Abdulmuhsin etTurki, Dâru Hicr, Cîze 1997, s. 562.

92 Belâzuri, age, C. I, s. 270.

93 İbn Kayyım, Muhacirler arasında bir kardeşleştirmenin olmadığı, hatta bunun makul olmadığı görüşündedir. Bunun sebebini de kendilerinin İslam uhuvvetine, mekân uhuvvetine ihtiyacı olmamalarına bağlar ve kardeşlik akdi olmaksızın aralarında neseb yakınlığı olarak görür. Bkz. İbn Kayyım el-Cevziyye, Zâdu'l-Meâd fi Hedyi Hayri'lİbâd, C. IV, thk. Şuayb el-Arnaût, Abdulkadir el-Arnaût, Mektebetu'l-Menaru'l-İslamiyye, Beyrut 1994, s. 64.

${ }^{94}$ Belazuri, age, C. I, s. 270.

${ }_{95}$ İbn Kesir, age, C. IV, s. 561.

${ }^{96}$ Mahmud Şakir, Islam Tarihi, C. I, çev. Ferit Aydın, Kahraman yay., İstanbul 1995, s. 399.

97 Mahmut Şakir, bu olayı maddiyat endeksli değerlendirmenin oryantalist bir bakış olduğunu ve bununla Müslümanları menfaat odaklı göstermeye çalıştıklarını söylemektedir. Bkz. Şakir, age, C. I, s. 399.

${ }^{98}$ Muhammed er-Râvî, el-Medinetu'l-Munevvere fì Ahdi'r-Risale, Camiatu'l-Melik Suud, Riyad 1992, s. 162.

${ }^{99}$ Buhari, Menakıbu'l-Ensar, 5.

${ }^{100} \mathrm{Sa}$ ‘d b. Rebî'nin uhuvvette kardeşi olan Abdurrahman b. Avf'a eşlerinden beğendiğini boşayıp verme olayı bu hususta verilecek sıra dışı bir örnektir. İfade şu şekildedir: "Ensar, benim malca en zenginleri olduğumu bilir. Malımı benimle senin aranda ikiye böleyim. İki eşim var, Bak onlardan hangisi senin hoşuna giderse onun ismini bana söyle de ben onu boşayayım. Boşayacağım o kadının iddeti geçince sen onunla evlenirsin dedi.” Bkz. Buhari, Menakıbu'l-Ensar, 3. Sa'd b. Rebî ile Abdurrahman b. Avf arasında geçen konuşmalar ve Sa'd'ın yapmaya çalıştığı fedakârlıklar için daha geniş olarak ayrıca bkz. Muhammed Ali Kâtibi, Sad b. Rebî‘ el-Ensari, Dâru'l-Kalem, Dımeşk 1993, s. 115-127. Fakat Sa'd'ın bu teklifi sadece eşin boşanması açısından değil, malların bölüşülmesi noktasında da Hz. Peygamber’in belirlediği çözüme aykırıdır.
} 
kaynaklarda yer alsa da bu tarz haberler, fedakârlıkları idealize etmeye hizmet etmektedir. Çünkü Hz. Peygamber'in uhuvvet tesisinin mal, mülk, meta ve heva-heves üzere olma durumu yoktur. ${ }^{101}$ Neticede Hz. Peygamber sorunun tespitini bizzat kendisi yapmış ve uygulanacak yöntemi üründe ortaklık olarak belirlemiştir. ${ }^{102}$ Dolayısıyla eldeki mal-mülk veya bunun yanında her şeyin paylaşımını içeren teklifler, resulün teklif ve çözümüne uygun değildir.

Hz. Peygamber Ensar-Muhacirun arasındaki kardeşlik bağını güçlendirme yanında, Ensar arasındaki samimiyet hususunda da çok çaba sarf etmekteydi. Hicretten önce Medineli Müslümanların Yahudilerle siyasi bağlarını koparması, ardından da İslam'ın burada egemen bir güç olması, Yahudi kabilelerini zor durumda bırakmıştır. Nitekim bir ortamda Yahudi liderlerden Şe‘s b. Kays, bunu bir firsata dönüştürerek Buâs günlerinden bahisle Evs-Hazrec'i birbirine yeniden kırdırmak istemiştir. Durumu öğrenen Hz. Peygamber, bu tavrın cahiliye tavrı olduğunu, ayrıca İslam'da kat edilen bunca mesafeden sonra bu tür düşüncelerin vahametini dile getirerek, Evs-Hazrec'i teskin etmiştir. ${ }^{103}$ Nitekim ifk hadisesi ardından bu hareketin başını çeken Abdullah İbn Übey'in Hazrec'den olması Evs-Hazrec arasında karşılıklı sataşmaların yaşanmasına sebebiyet vermiştir. ${ }^{104}$

Hz. Peygamber İslam'a hizmetleri olan kabileleri sayarken muhtemelen kaynaşmalarını artırmak adına Benî Kayle'nin Evs-Hazrec kollarını ismen zikretmemiş ve Ensar sıfatıyla yetinmiştir. ${ }^{105} \mathrm{~Hz}$. Peygamber belki de bu isimlendirme ile başta Evs-Hazrec olmak üzere Arap kültüründeki asabiyet ruhunu izale etmek istemiştir. ${ }^{106} \mathrm{~Hz}$. Peygamber Medine'ye hicreti ardından dengeleri çok iyi tahlil etmiş ve Ensar-Ensar ve Ensar-Muhacirun kardeşliğini akamete uğratacak hiç bir şeye firsat tanımamıştır. Ensar içinde de bölünme ve küskünlüğe firsat vermemek için azami gayret göstermiştir. Örneğin Medine'deki kabileler içinden mümessil seçerken "Cibril Benim için seçiyor" demiştir. ${ }^{107}$ Belki de bu durum Ensar arasında muhtemel bir kırgınlığın da önüne geçmiştir. Herhangi bir alınganlık olmaması için her kabileden seçtiği nakiplerin içinde Benî Neccar'dan da bir temsilci vardı. Ancak Hz. Peygamber, Esad b. Zurâre'nin vefatı üzerine Benî Neccar'dan yeni bir nakib atamamış ve akrabalığa binaen kendisini Benî Neccâr'ın temsilcisi olarak ilan etmiştir. ${ }^{108}$

Hz. Peygamber Medine dönemi boyunca Ensar'ın desteği ve fedakârlıklarını daima övmüştür. Ensar'ın geçimi ziraattan olmasına rağmen cephede hep ön safta olmuştur. Ensar hiçbir mücadelede ganimet odaklı hareket etmemiş olup, bunun tek istisnası Huneyn'dir. Hevazin'de yapılan taksimatta ganimetten pay almamasindan ziyade, tulekaya pay verilmesi

\footnotetext{
101 er-Ravi, age, s. 162.

102 İbn Kesir, age, C. IV, s. 565.

103 Âli İmran 3/99. ayetinin nüzul sebebi için bkz. Taberî, Camiu'l-Beyân, C. V, s. 627-628.

104 Üseyd b. Hudayr, "Eğer iftira haberlerini yayanlar Evs'ten ise biz onları sustururuz, Hazrecli kardeşlerimizden iseler yapılması gerekeni bize emret yapalım deyince Sa'd b. Ubâde "Vallahi söz konusu şahıslar Hazrec'den olduğu için böyle konuşuyorsun, senin kabilen olan Evs’ten olsalar böyle demezdin” sözüne Useyd, "Yalan söylüyorsun ve sen bir münafiksın ve münafikları savunuyorsun" diye cevap verince insanlar birbirinin üzerine yürüdü ve neredeyse çok kötü şeyler olacaktı. Bkz. İbnu'l-Esîr, age, C. II, s. 85.

${ }^{105}$ Ebû Hureyre anlatıyor: "Kureyş, Ensar, Cüheyne, Müzeyne, Eslem, Eşcâ ve Gıfar benim dostlarımdır. Onların da Allah ve Resulü’nden başka dostları yoktur.” Bkz. Buharî, Menakıbu'l-Ensar, 6.

${ }^{106}$ Semhûdî, age, C. I, s. 408.

${ }^{107}$ İbn Sa'd, age, C. I, s. 189.

${ }^{108}$ Hamidullah, Benî Neccar'da lider konumunda olan münafik Abdullah b. Übey’i veya kibri sebebiyle Sa'd b. Ubâde’yi saf dışı bırakmak için böyle yapıldığını iddia eder. Bkz. Hamidullah, s. 144. Tabiî ki İbn Übey’in nifak hareketinin lideri olduğu tüm Müslümanların malumu idi. Ancak Sa'd b. Ubâde için böyle bir tavır sergilendiğini söylemek biraz şaşırtıcıdır. Hamidullah muhtemelen Sakife'deki çıkışı sebebiyle kendi için böyle bir değerlendirmede bulunmaktadır. Çünkü kendisi başta Hz. Peygamber olmak üzere Müslümanlar için oldukça fazla fedakârlık yapmıştır.
} 
Ensar'1 olumsuz yönde etkilemiş olsa gerekir. ${ }^{109}$ Ancak bunu duyan Hz. Peygamber onlarla bir toplantı yapıp kendilerine şöyle demiştir: "Ey Ensar topluluğu; kendi kendinize hakkımda söylediğiniz bazı söylentiler de neyin nesi? Size geldiğimde dalalet içinde bulup sizi hidayete erdirmedim mi? Sizi fakr-u zaruret içinde bulup zenginleştirmedim mi? Aranızda düşmanlık varken kalplerinizi birleştirmedim mi? Onlar da "Kesinlikle öyle, Allah ve Resulü en cömert ve en faziletli olandır" diyerek cevap vermişlerdir. Ardından Hz. Peygamber "Bana cevap vermeyecek misiniz? Eğer 'bize yalanlanmış olarak geldin seni tasdik ettik; horlanmış olarak geldin, sana yardım ettik; kovulmuş olarak geldin, seni himaye ettik; fakirken seni destekledik' deseniz doğru söylemiş ve doğruluğunuz onaylanmış olurdu." Peygamber'i ve muhacirleri yerinden yurdundan eden Kureyş'e karşı bir tavır sergilemiştir. Bu olayda Ensar'ın bir başka çekincesinden bahsetmek gerekir. O da Hz. Peygamber'in Kureyş'e çok yakın davranması ve kendilerini terk etme ihtimalidir. ${ }^{111}$ Aslında bu tavır, Ensar'ın bir çıkar kavgası peşinde olduğunu göstermez. Aksine buradaki amaçları, İslam'ın ev sahipliğinin ve Medinetu'r-Resul niteliklerinin devamlılığını sağlamaktır. ${ }^{112}$ Zaten bunun sözünü akabe biatinde Hz. Peygamber'den almışlardı. Ensar, ganimeti hedefleyen ve maddiyat üzerinden olaylara bakan bir karakterde değil, tehlikeye karşı cansiperane hareket eden bir yapıdadır. Nitekim Hz. Peygamber "Sizler korku anında çoğalıp talep söz konusu olunca da azalırsınız"113 diyerek kendilerini övmüştür. Resulullah, Ensar'ın vazife ve diğergamlıklarını fazlasıyla yerine getirmeleri ardından kendilerini artık cennet nimetini beklemekle müjdelemiştir.

Muhacirler, İslam'ı yaşamak uğrunda her imkânı denemişlerdir. Şüphesiz şehirlerin anası sayılan Mekke'yi terk etmeleri onlara ağır gelse de bunu, dinleri için yapmışlardır. Bu husus Hz. Peygamber'i de duygusal anlamda çok etkilemiştir. Medine'deyken ise İslam'a yardımda sınır tanımayan Ensar'ı överken yine hicretin önemini dile getirmiş ve "Hicret olmasaydı Ensar'dan birisi olurdum" "114 demiştir. Demek ki İslam'da Muhacir ve Ensar karakterleri birbirinin alternatifi olamayacak derecede ayrı ayrı önem arz etmektedir. Zaten bu durumu fark eden akabe ehlinden bazıları, ilk muhacir kafilesi ardından Mekke'ye gelerek muhacirlere eşlik etmişlerdir. Zekvan b. Abdulkays, Ukbe b. Vehb b. Kelede, Abbas b. Ubade b. Nadle ve Ziyad b. Lebîd'den oluşan bu topluluk ${ }^{115}$ hem Ensar hem Muhacir sevabına erişenlerdir.

\section{Ensar'ın Çabaları}

Hz. Peygamber'in tebliğde bulunduğu Arap kabilelerden, İslam'ı kabul, himaye ve tebliğe yardımcı olmak üzere 3 şey talep etmekteydi. ${ }^{116}$ Buradaki himayenin amacı da şahsi can güvenliği değildir. Çünkü kendisi zaten Mekke'de himaye altındadır. Bunun en büyük göstergesi Mut'im b. Adiy'in civar hakkı ve yine akabe görüşmelerinde amcası Abbas'ın belirttiği üzere ${ }^{117}$ kabilesinin onun hâmisi olduğu gerçeğidir. Dolayısıyla himayeden maksat, İslam'ı tebliğde güvenli bir ortamın teminidir. Çünkü hicret, Hz. Peygamber'in, tebliğin önündeki engelleri kaldırma çabası olarak değerlendirilmelidir. ${ }^{118}$ Himayenin riskleri etraflı bir şekilde bizzat Evs-Hazrec tarafından dile getirilmiştir. O günün şartlarında böyle bir şeyi

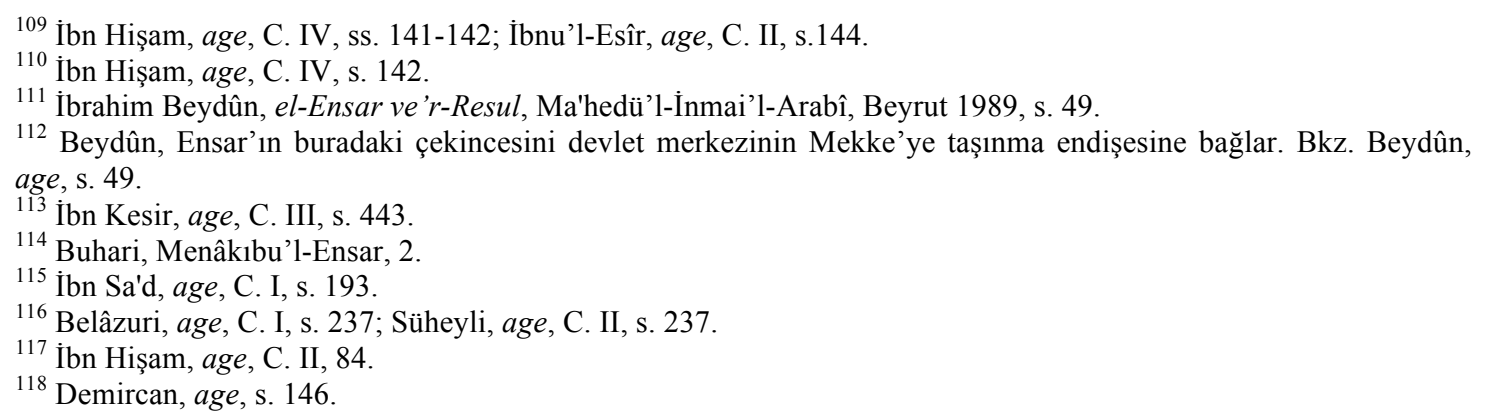


üstlenmek, Arap toplumunda bir ayrışma ve muhtemelen Evs-Hazrec'in başta can olmak üzere mal-mülk kaybı demekti. ${ }^{119}$

Genelde Ensar'ın Hz. Peygamber'i ve muhacirleri sadece Medine içinde koruma ile görevli olduğu tespiti yapılır. Aslında bunun dayanağı Bedir savaşından önce $\mathrm{Hz}$. Peygamber'in Ensarla 1srarla yaptı̆ğ görüşmedir. Ensar bu görüşmede Hz. Peygamber'e, vereceği her kararın uygulayıcısı olacağını söylemiştir. Bedir'de Ensar'ın Medine dışında savaşıp savaşmayacağı değil, Kureyş ile girişilecek ilk ve önemli bir çarpışmaya dair bir değerlendirme söz konusudur. Çünkü Medine'den çıkış amacı savaş değil, kervandır. Bunun için her zamankinden daha fazla teyide ihtiyaç vardır. Bunun bir diğer kanıtı da Sa'd b. Muaz'ın konuşmasıdır. Burada sefere çıkmayan ve Medine'de kalan Ensar adına özür dileyen Sa'd şöyle demiştir: "Ya Resulallah; biz geride kabilemizden sana daha fazla sevgi duyan ve daha itaatkâr bir topluluk bıraktık, onların da cihada katılma istek ve niyetleri var. Eğer onlar senin düşmanla karşılaşacağını bilseler Medine'de kalmazlardı. Onlar çıkışımızın sadece kervana yönelik olduğunu zannettiler." ${ }^{20} \mathrm{Bu}$ ifadeler, savaş istişaresinde bulunamayan Ensar'ın bir kısmı içindir. Kendilerinin, İslam'1 himaye kararlılığında olması, Ensar'ın görevinin İslam'ı sadece Medine içinde himaye ile sınırlı olduğu çıkarımına tezat oluşturur. Ayrıca ikinci akabe biatı bir savaş biatıdır ve bu biat tamamlandığında Abbas b. Ubâde b. Nadle; "Ya Resulallah! Seni hak ile gönderene yemin ederim ki arzu edersen Mina ehline kılıçlarımızla saldırırız" deyince Hz. Peygamber "Biz bununla emr olunmadık" diyerek cevaplamıştır. ${ }^{121} \mathrm{Bu}$ ifade, Hz. Peygamber'i himaye ve İslam uğrunda savaşın Medine ile sınırlı olmadığı ve Ensar'ın her an İslam için mücadeleye hazır olduğunu göstermektedir.

Ensar karakterini izah edecek kelimelerden başlıcası, fedakârlıktır. Hâlbuki İslam uğrunda canını dişine takarcasına verdikleri mücadeleler ve savaşlarda en ön safta yer almaları ve şehadetleri bu kavram içinde pek anlatılmaz. Örneğin Hz. Peygamber'in en zor durumlarından birisi olan Huneyn gazvesinde ani bir saldırı ardından Müslüman ordusu dağılmıştı. Bu esnada orduyu toparlamak için yoğun çaba sarf eden Hz. Peygamber önce "Ey Ensar", diye nida etmiş ve çağrısına ilk icabet eden de Ensar olmuştur. ${ }^{122}$ Çünkü Ensar kendisini İslam'ı savunmaya adamıştır. Hatta ileride Hubâb b. Münzir, Sakife'de hilafetin Ensar'ın hakk1 olduğunu savunurken kendilerinin askeri katkılarına vurgu yapacak ve Ensar'1 "İslam'ın askeri birliğì" olarak tanımlayacaktır. ${ }^{123}$ Dahası, Sakife'de Ensar'dan çıkan tek halife adayının bile halife olmak için Ensar olmayı yeter neden olarak görmesi manidardır.

Ensar'ın İslam'ı kabul etmekle yaptıkları en büyük fedakârlık, yurtlarının hedef alınmasını göze almalarıdır. Zaten bunu akabede mal ve liderlerin bu yolda riske edilmesi olarak tanımlamışlardır. Yarımadanın zengin Mekkeli tüccarları, Mekke'yi sırf inancı için terk edenlerin mallarına el koyarken, ${ }^{124}$ dar gelirli Medineli Müslümanlar ellerindeki imkânları sığınmacılarla paylaşmak için yarışmaktaydı. Uhuvvetten önce muhacirler bölük bölük Medine'nin farklı mahallelerinde Ensar evlerine yerleştirildiler. Ensar'ın ilk etapta yaptığı maddi fedakârlık muhacirlere mekân tahsisidir. Nitekim Evs-Hazrec, Ensar olma sözünü akabede vermiştir. Bu sözleşme, maddi manevi her türlü fedakârlığı içeriyordu. Zaten Hicret ardından Medineli Müslümanların takındığı tavır Kuran'da izah edilmiştir. ${ }^{125}$ Buna göre gazve

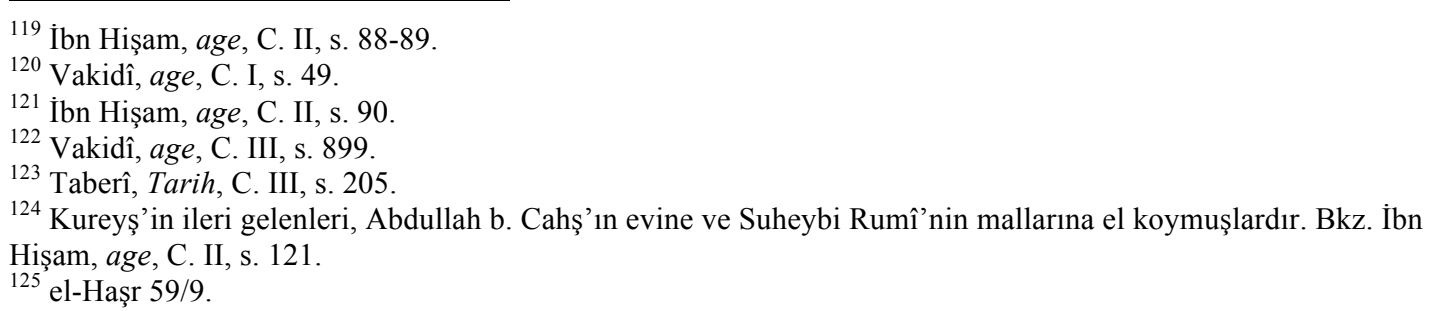


ve seriyyelerle elde edilen maddi kazanımlar hususunda Hz. Peygamber muhacirlere pozitif ayrımcılık yapmıştır. Bunun nedeni yer ve yurtlarını İslam adına terk etmiş olmalarıdır. Hem kıt imkânları hem de hicret nedeniyle artan nüfus yapısı, Ensar'ı ciddi bir ekonomik darboğaza itmiştir. Ancak kendileri mallarını terk eden Müslümanlara ellerindekini ve ganimetten hak ettiklerini paylaşarak hicret fedakârlığına karşı misliyle mukabele etmişlerdir.

Bedir savaşı öncesinde gerçekleşen seriyye ve gazvelerin hiç birisinde hedef Kureyşle savaş olmayıp, Kureyş başta olmak üzere civar kabilelere İslam'ın gücü ve caydırıcıllı̆gnı hissettirmektir. Abdulah b. Cahş seriyyesinde gerçekleşen çatışma durumu ise $\mathrm{Hz}$. Peygamber'in eleştirileri üzerinden değerlendirildiğinde yapılanın, kastı aştığını gösterir. Dolayısıyla Kureyş'in adeta can damarı olan ticaret yollarını güvensiz hale getirmek veya Müslümanlardan gasp ettikleri mal mülkü geri almak için düzenlenen bu seriyyelere ${ }^{126}$ Ensar'ın katılmaması, Medine dışındaki mücadelelerden muafiyet anlamına gelmez.

Ensar'ın Hz. Peygamber'i himaye kararlılı̆̆ savaş meydanında da had safhadadır. Örneğin Bedir savaşında meydanının gerisinde bir otağ yapılması teklifi ve buranın himayesi yine Ensar tarafından sağlanmıştır. Ensar Hz. Peygamber'e adeta bir emanet olarak baktığı için onu himaye uğrunda en önde olmuştur. Dolayısıyla İslam için adeta kahraman bir edayla hareket eden Evs-Hazrec hakkında yapılan "İnsanların lisan bakımından en uzunları, kılıç bakımından en keskinleri”'127 tanımı, hakikaten yerinde bir tanımdır. Ensar'ın İslam'a en büyük desteği, bu uğurda hayatını ortaya koymuş olmasıdır. Tebük seferinde binek bulamadığından ötürü savaşa katılamayan ve Hz. Peygamber'den de gerekli teçhizatı temin edemeyen yedi kişilik bir grup vardır ki bunlar bekkaûn (ağlayanlar) olarak nitelenmişlerdir. Benî Süleym'den Irbad b. Sâriye es-Sülemî haricinde bu şahısların hepsi Evs-Hazrec'dendi. ${ }^{128}$

Evs-Hazrec İslam'a yurt oluşturmuş, resule hayat ve tebliğ garantisi vermiş ve davetin ev sahipliğini yapmayı kabullenmiştir. Bu duruşları nedeniyle kendilerini Hz. İsa'nın havarileri olarak tanımlayan ifadeler ${ }^{129}$ oldukça yerindedir. Hz. Peygamber, seçtiği nakipleri kabilelerin temsilcileri olmaları nedeniyle Hz. Musa'nın seçtiği 12 nakibe, kabilelerine kefil olmaları nedeniyle de İsa'nın havarilerine benzetmiştir. ${ }^{130}$

\section{Sonuç}

Hazrec kabilesinden altı kişinin İslam'ı kabul etmesi ve bu kabulün Evs-Hazrec arasında kitlesel bir hale dönüşmesi sıra dışı bir olaydır. Hazrecli altı kişinin İslam'ı kabulünde ve Ensar karakterinin oluşumunda birç̧ok faktör bir arada düşünülmelidir. Evs-Hazrec, aralarında yaklaşık yüz yirmi yıl süren iç çatışma ortamının bıkkınlığını İslam'ı kabul için bir firsata dönüştürmüştür. Evs-Hazrec Muhacirlere Ensar olmakla, aslında eski yaşadıklarından daha büyük bir meşakkate kucak açmıştır. Kendileriyle Akabe mevkisinde yapılan görüşmelerde Evs-Hazrec, yaşadığı acılar, çatışmalar, iç savaşlar ve en önemlisi asabiyetle şekillenen yaşamlarını değiştirmek için bir tercih yapmıştır. Muhacirler için her fedakârlığı yapan EvsHazrecli Müslümanlar, artık Ensar diye anılmaya başlamış ve Ensar, Medineli Evs-Hazrec Müslümanları için bir üst kimlik olmuştur. Arap kültüründe İslam'dan önce ve sonra, kabile faktörü siyasal ve sosyal hayatı şekillendiren unsurlardan olsa da Allah ve Resulü tarafından böyle nitelendirilmiş olmaları, Ensar sıfatını tercih etmelerinde etkili olmuştur. Ayrıca bu isim kullanıldıkça ve buna vurgu ve atıf yapıldıkça Medine'de Evs-Hazrec arasındaki kaynaşma ve

${ }^{126}$ Tahir Ali Akle, el-Ensar Remzu'l-Îsâr ve Dahiyyetu'l- Esere, Dâru'l-Hâdi, Beyrut 2001, s. 75.

127 İbn Sad, age, C. I, s. 185.

${ }^{128}$ Vakidî, age, C. III, s. 994.

129 Samiye Menisi, bu çıkarımı Saff suresi 14. ayete dayandırır. Bkz. Samiye Menisi, el-Ensariyyat mine'sSahâbiyyat, Dâru'l-Fikri'l-Arabî, Kahire 2002, s. 13.

${ }^{130}$ İbn Sa'd, age, C. I, s. 189. 
hayırda yarışma suretiyle aralarındaki kabilevî çatışma olasılı̆̆ her geçen gün azalmıştır. İslam'da, sahip olunan iyi niteliklerle övünmek hoş görülmemesine rağmen Evs-Hazrec, Ensar kimliği ile daima övünmüştür. ${ }^{131}$ Bunda vahyin ve Hz. Peygamberin yönlendirmesi ve taltiflerinin etkisi büyüktür.

Ensar karakteri, akabe ve hilafet olmak üzere iki biat arasında değerlendirilmesi gerekir. Akabe biatı ile oluşan Ensar kimliği, risaletin on yıllık Medine döneminde fedakârlı̆̆ın her türlü örneğini vermiştir. Bu duruş, risalet takdiri yanında ilahi takdiri de kazanmıştır. Ensar, hilafet biatı ile Hz. Peygamber'den sonra da Müslümanların birlik ve bütünlügünün devamlılığına yardımcı olmuştur. $\mathrm{Bu}$ durum Ensar kimliğinin muvakkat olmadığının göstergesidir. Evs-Hazrec, Hz. Peygamber'in davet ettiği onlarca kabile arasından İslâm'ı kabul ederek önce kendilerine Ensar olmuş, ardından muhacirlere sonra da karşılaştıkları her topluluğa bu ruhla yaklaşmışlardır.

Evs-Hazrec her iki akabede kabul ettiği şartlar doğrultusunda önce İslam'1 aralarında yaymış, komşularıyla olan siyasi ve sosyal ilişkilerini gözden geçirmiş ve kendi aralarındaki kardeşlik bağını İslam'la tekrardan hatırlamıştır. Ensar'ın tavır ve tutumları, İslam Tarihi'nde İslam ve Müslümanlar için yapılabilecek fedakârlıklar hususunda başlıca örneklerdendir. Hicretten sonra Evs-Hazrec ve Ensar-Muhacir arasında zaman zaman sorunlar yaşanmışsa da bu durumlar, bizzat Hz. Peygamber'in müdahalesi ile düzeltilmiştir. Evs-Hazrec, Arabistan'ın yerleşik kültürünün temel kodu olan yok ederek var olma anlayışını, Ensar kimliği ile sonlandırmıştır. Bu kadar önemli bir misyonu gerçekleştiren Ensarı anlayabilmek için bu karakterin oluşumuna etki eden şartların bir arada ve iyi anlaşılması gerekir.

\section{Kaynakça}

AKLE, Tahir Ali, el-Ensar Remzu'l-Îsâr ve Dahiyyetu'l-Esere, Dâru'l-Hâdi, Beyrut 2001.

ALİ, Cevad, el-Mufassal fi Tarihi'l-Arab Kable'l-İslam, у.у.,1993.

BUHÂRÎ, Ebu Abdullah Muhammed b. İsmail (ö.256/870), Sahîhu'l-Buhârî, C. II, haz. Bedreddin Çetiner), Çağrı yay., İstanbul 1992.

BELÂZURÎ, Ebû'l-Abbas Ahmed b. Yahya, Ensâbu'l-Eşrâf, C. I, thk. Muhammed Hamidullah, Dâru'l-Meârif, Misır 1959.

BEYDÛN, İbrahim, el-Ensar ve'r-Resul, Ma'hedu'l-İnmai'l-Arabî, Beyrut 1989.

el-CABİRÎ, Muhammed Abid, Arap-İslam Siyasal Aklı, çev. Vecdi Akyüz, Kitabevi yay., İstanbul 2001.

DEMIRCAN, Adnan, Nebevi Direniş Hicret, Beyan Yay., İstanbul 2015.

HAMIDULLAH, Muhammed, Islam Peygamberi, çev. Mehmet Yazgan, Beyan Yay., İstanbul 2011.

HASAN, Hasan İbrahim, İslam Tarihi, C. I, çev. İsmail Yiğit, Sadreddin Gümüş, Kayıhan Yay., İstanbul 2011.

İBN ABDİLBERR, Yusuf en-Nemerî (ö.463/1071), ed-Dürer fî İhtisari'l-Meğazî ve'sSiyer, $\quad$ thk. Şevki Dayf, Dâru'l-Meârif, Kahire 1991.

İBN ABDİRABBİH, Ahmed el-Endelûsî, el-íkdu'l-Ferîd, C. VI, thk. Abdülmecid etTerhînî, Dâu'l-Kutubil İlmiye, Beyrut 1983.

${ }^{131}$ Ali, age, C. IV, s. 140. 
İBNU'L-ESÎR, Ebu'l-Hasan İzzeddin, el-Kâmil fi't-Tarih, C. I, thk. Ebu'l-Fida Abdullah el-Kâdî, Dâru'l-Kutubi'l-İlmiyye, Beyrut 1987.

İBN HIŞAM, Ebû Muhammed Cemaleddin (ö.218/833), es-Sîretu'n-Nebeviyye, C. I, thk. Mustafa es-Sekka, İbrahim el-Ebyâri, Abdülhafız Şelebî, Dâru İhyai't-Turâsi'lArabi, Beyrut, t.y.,

İBN KAYYIM el-CEVZIYYYE, Şemseddin Ebû Abdillah (ö.751/1350), Zâdu'l-Meâd fì Hedyi Hayri'l-İbâd, C. IV, thk. Şuayb el-Arnaût, Abdulkadir el-Arnaût, Mektebetu'l-Menâri'l-İslamiyye, Beyrut 1994.

İBN KESÎR, İmaduddin Ebû'l-Fidâ (ö.774/1373), el-Bidâye ve'n-Nihâye, C. IV, thk. Abdullah b. $\quad$ Abdulmuhsin et-Turki, Dâru Hicr, Cîze 1997.

İBN MANZÛR, Ebû'l-Fazl Muhammed (ö.711/1311), Lisânu'l-Arab, thk. Emin Muhammed Abdulvehhab, Muhammed Sadık el-Ubeydi, Dâru İhyai Turâsi'l-Arabî, Beyrut 1999.

İBN SA'D, Ebû Abdullah Muhammed (ö.230/844), Kitâbu't-Tabakâti'l-Kebîr, thk. Ali Muhammed Ömer, Mektebetu'l-Hanci, Kahire 2001.

İBN ZEBÂLE, Muhammed b. Hasan(ö.199/814), Ahbâru'l-Medine, Merkezu Buhûs ve Dirâsâti'l-Medineti'l-Münevvere, Medine 2003.

KAPAR, Mehmet Ali, “Eyyamu'l-Arab”, DIA, İstanbul 1995, XII, s.14-16.

KATİBÎ, Muhammed Ali, Sa 'd b. Rebî‘ el-Ensârî, Dâru'l-Kalem, Dımeşk 1993.

LINGS, Martin, Hz. Muhammed'in Hayatı, çev. Nazife Şişman, İnsan Yay., İstanbul 2012.

el-MAKRÎZÎ, Takıyyüddin Ahmed (ö.845/1442), Imtâu'l-Esmâ, thk. Muhammed Abdülhamid en-Nemîsî, Dâru'l-Kutubi'l-İlmiyye, Beyrut 1999.

MENISİ, Sâmiye, el-Ensariyyat mine's-Sahâbiyyat, Dâru'l-Fikri'l-Arabî, Kahire 2002.

NUMÂNÎ, Mevlânâ Şiblî, Son Peygamber Hz. Muhammed, çev. Yusuf Karaca, red. Muharrem Tan, İz Yay., İstanbul 2012.

er-RAVI, Muhammed, el-Medinetu'l-Munevvere fì Ahdi'r-Risâle, Mektebetu'l-Ubeykan, Riyad 2006.

es-SEMHÛDÎ, Nureddin Ali (ö.911/1506), Vefâu'l-Vefâ bi Ahbâri Dâri'l-Mustafa, C.I, thk. Muhammed Muhyiddin Abdülhamid, Dâru'l-Kutubi'lİlmiyye, Beyrut 1984.

es-SÜHEYLÎ, Ebû'l-Kâsım Abdurrahman(ö.581/1185), er-Ravzu'l-Unûf fî Şerhi'sSireti'n- Nebeviyye li İbn Hişam, Dâru'l-Kutubi'l-İlmiyye, Beyrut, t.y.

SALLÂBÎ, Ali Muhammed, es-Sîretu'n-Nebeviyye, Dâru'l-Marife, Beyrut 2012.

ŞAKİR, Mahmud, İslam Tarihi, C.I, çev. Ferit Aydın, Kahraman yay., İstanbul 1995.

et-TABERÎ, Ebû Cafer Muhammed, Camiu'l-Beyân An Te'vîli Âyi'l-Kuran, C.V, thk. Abdullah $b$.

Abdulmuhsin et-Turki, Dâru Hicr, Cize, 2001.

Tarihu'r-Rusûl ve'l-Mulûk, C. II, thk. Muhammed Ebû'l-Fazl İbrahim, Dâru'lMeârif, Kahire, t.y. 
el-VAKİÎ,, Ebu Abdullah Muhammed b. Ömer, Kitabu'l-Meğâzî̀, ed. Marsden Jones, Oxford University Press, London 1966.

WATT, W. Montgomery, Muhammad at Medina, Oxford University Press, Great Britain 1956.

ZEYDAN, Corci, Kitabu'l-Arab Kable'l-İslam, Matbaatu'l-Hilal, Misır 1922.

ZEYNEL ABİDİN, Muhammed Surûr, Dirâsât fî's-Sireti'n-Nebeviyye, Dâru'l-Erkam, Birmingham 1988. 